\title{
Late Ordovician-earliest Silurian palynomorphs from northern Chad and correlation with contemporaneous deposits of southeastern Libya
}

\author{
Alain Le Hérissé, Florentin PARIS \& PhiLIPPE Steemans
}

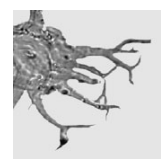

\begin{abstract}
Well preserved assemblages of cryptospores, chitinozoans, acritarchs, leiospheres, tasmanitids, colonies of Gloeocapsomorpha, scolecodonts and eurypterid fragments from 23 core samples of the Moussegouda core hole in the Erdi Basin, northern Chad, and from two samples from well KW-2 in Kufra Basin, South East Libya are investigated. These palynomorphs were recovered from the southernmost North African marine deposits of Late Ordovician and possibly early Silurian age. The palaeoenvironment evolves from late Hirnantian glacio-marine diamictites to silt-dominated sequences suggesting a marginal marine environment of possibly latest Hirnantian to earliest Rhuddanian age (post-elongata-pre-fragilis chitinozoan assemblages). The recovered palynomorph assemblages are compared and correlated with contemporaneous assemblages recorded in other northern Gondwana localities (Mauritania, Morocco Algeria, Libya, Africa, Saudi Arabia, Jordan), and in South Africa, in order to evaluate possible effects of the ice cap melting on palynomorph assemblages and sedimentation. Our goal is also to improve the regional biostratigraphy across the Ordovician-Silurian boundary. The composition of the recovered palynomorph assemblages, with mixed terrestrial and marine microflora, suggests that the topmost Ordovician or earliest Silurian in northern Chad and southeastern Libya, reflects nearshore conditions, with obvious fresh water influences. The lack of black shale or grey shale in the uppermost Ordovician and of "hot shale" in the lower Silurian in these areas, and their replacement by siltstones, are probably related to an isostatic readjustment that rapidly starved the marine sedimentation in the areas previously overlain by a thick ice cover during the climax of the Hirnantian glaciation. Tasmanites tzadiensis Le Hérissé sp. nov. and Euconochitina moussegoudaensis Paris sp. nov., two new palynomorphs of biostratigraphical interest are described and illustrated. - Key words: northern Gondwana, Chad, Libya, Ordovician-Silurian boundary, acritarchs, chitinozoans, spores, biostratigraphy, palaeoenvironment.
\end{abstract}

LE HÉRISSÉ, A., PARIS, F. \& STEemANS, P. 2013. Late Ordovician-earliest Silurian palynomorphs from northern Chad and correlation with contemporaneous deposits of southeastern Libya. Bulletin of Geosciences 88(3), 483-504 (10 figures). Czech Geological Survey, Prague. ISSN 1214-1119. Manuscript received August 29, 2012; accepted in revised form January 10, 2013; published online February 18, 2013; issued July 3, 2013.

Alain Le Hérissé, UMR 6538 du CNRS, Université de Brest, CNRS, UMR 6538 Domaines Oceaniques, Institut Universitaire Euopéen de la Mer, CS93837, 6 Avenue Le Gorgeu, 29238, Brest, Cedex, France; alain.le.herisse@ univ-brest.fr • Florentin Paris, Rue des Jonquilles, 35235 Thorigné-Fouillard, France (Géosciences-Rennes, UMR 6118 du CNRS, Université de Rennes 1, 35042 Rennes-cedex, France); florentin.paris@orange.fr • Philippe Steemans, University of Liège, Paleobotany, Paleopalynology and Micropaleontology, Allée du 6 Août, Bât. B-18, parking 40, B - 4000 Liège 1, Belgium; P.Steemans@ulg.ac.be

Transitional Ordovician-early Silurian strata in North Africa and the Middle East, have been extensivelly investigated, as in many basins the Hirnantian glacially-related deposits constitute significant reservoirs (Hirst et al. 2002, Le Heron et al. 2009). These deposits are generally sealed by latest Ordovician (Armstrong et al. 2005) to Rhuddanian (Lüning et al. 2005) organic rich black shale and "hot shale", which represent the most important Palaeozoic source rocks of northern Gondwana regions. Information about the presence/absence of the "hot shale" and the development of anoxia, but also accurate dating of the series, is crucial for improved source potential and risk evaluations for hydrocarbon exploration (Lüning \& Fello 2006). The final melting of the Hirnantian ice cap, as well as the pattern and timing of the post glacial transgression are controlled mainly by the topography of the glacial floor, and by the effects of deposition within the palaeovalleys. Reactivation of ancient tectonic structures occurred also during the post-glacial isostatic rebound (Le Heron et al. 2006). Palaeontological techniques proved to provide the most appropriate data for establishing an accurate timing of the successive events and to document climate changes and 


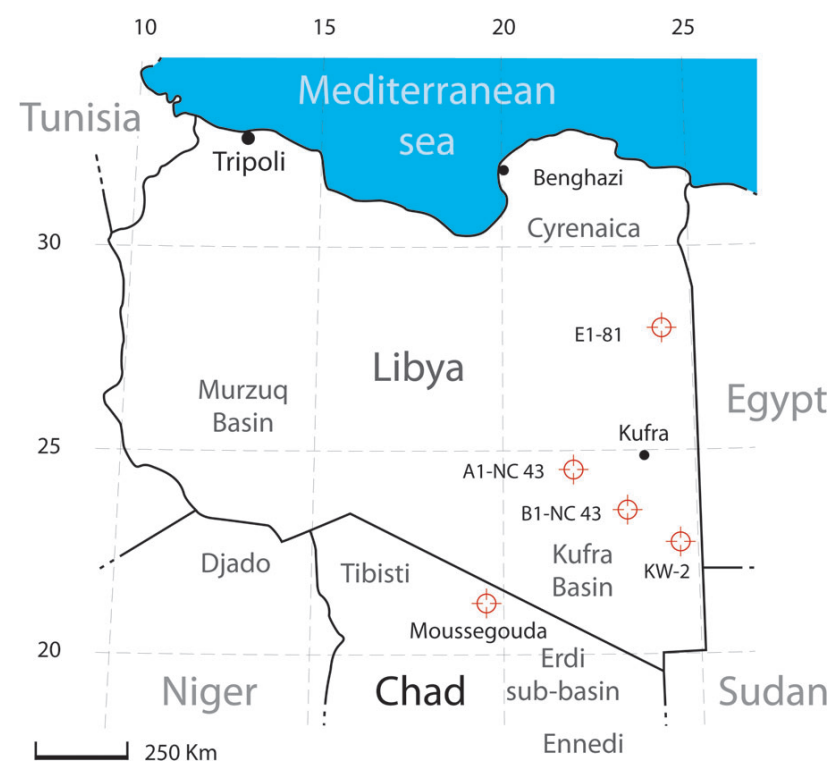

Figure. 1. Sketch map of north-east Africa and location of the study area, with position of core sections studied and mentioned in reference.

environment modifications during Late Ordovician and early Silurian times. Planktic graptolites are generally common in black shale formations and have been widely used for establishing biostratigraphical subdivisions, for correlations and for dating hydrocarbon source rocks (Massa \& Jaeger 1971; Legrand 1981; Štorch \& Massa 2006; Fello et al. 2006; Loydell 2007, 2012; Loydell et al. 2009). Graptolites are mainly collected from outcrops samples. On the contrary, palynomorphs, which are usually absent in Saharan exposures (due to deep weathering) are generally abundantly and continuously represented throughout the subsurface sequences. Palynostratigraphy therefore has been widely used for oil exploration in North Africa since the early 1960s (see main references in Vecoli \& Le Hérissé 2004, Butcher 2009, Paris et al. 2012). New developments in palynology aim to provide high-resolution biostratigraphical models based on more accurately documented range of the recorded species and on the identification of bioevents of potential chronostratigraphic significance, e.g. palynozonations proposed for the Saudi Arabian Kingdom (Al-Hajri \& Owens 2000, Paris et al. 2013a).

Here we report on a sequence of palynomorph assemblages from Late Ordovician and possibly earliest Silurian sediments in the southern part of the present day Sahara, in southeast Libya and northern Chad. Contemporaneous deposits are poorly known in this area, due to the scarcity of suitable core holes and to their position far to the South, i.e. localities close to or periodically overlain by the Hirnantian ice cap. The lack of younger Silurian marine sediments is likely related to the position of the former ice cap (post glacial isostatic readjustement), and to subsequent erosion, which removed the few possible continental deposits. The aims of this paper are to provide a subsurface biostratigraphic control, and to discuss the palaeoenvironmental conditions of their deposition compared to sequences known elsewhere in Mauritania, Morroco, Algeria, Libya, Saudi Arabia, Jordan or Tunisia.

\section{Regional geological setting}

This paper deals with core material from two separate areas of southeast Libya and northern Chad. The two investigated boreholes and other wells referred to in the text are plotted on Fig. 1. The Moussegouda shallow borehole $\left(21^{\circ} 40^{\prime} \mathrm{N} / 18^{\circ} 36^{\prime} \mathrm{E}\right)$ was drilled in northern Chad in the Erdi Basin, in the early 1960s. In some publications (e.g., Lüning et al. 1999), the Erdi Basin in northern Chad and the Mourdi Basin in northwest Sudan are considered as extensions of the Kufra Basin. Several studies of the Palaeozoic succession in the Chadian and Sudanese parts of the Kufra Basin have been published (Klitzsch 1981, Hissene Mahamoud 1986, Klitzsch \& Wicisk 1987, Klitzsch et al. 1993, Semtner \& Klitzsch 1994). Nevertheless, this area is clearly underexplored compared to other basins, such as the Murzuk or Ghadames basins in Libya. The shallow well KW-2 $\left(22^{\circ} 56^{\prime} \mathrm{N} / 24^{\circ} 19^{\prime} \mathrm{E}\right)$ was drilled by AGIP in 1975 in the Jebel Asba area, Kufra Basin SE Libya. The KW-2 well is one of the few places in the Kufra Basin where the basal part ( $54 \mathrm{~m}$ ) of the Tanezzuft Formation was encountered. This borehole and elements of biostratigraphy by means of graptolites and chitinozoans are mentioned in several publications (Bellini \& Massa 1980, Grignani et al. 1991, Lüning et al. 1999, Thusu et al. 2013). The middle part of the grey-green shale unit, between 18 and $31 \mathrm{~m}$, yielded the species "Climacograptus medius" (Normalograptus medius, see Loydell 2012) and some chitinozoans suggesting a latest Ordovician to early Silurian age. The palynozonation of Grignani et al. (1991) is reevaluated in this paper.

Concerning the Moussegouda core hole, based on preliminary sedimentological evidence cores 9 and 10 (dispersed coarse quartz grains) were referred to the Memouniat Formation of Late Ordovician age, and cores 1 to 8 (greyish siltstone) to the Silurian Tanezzuft and Akakkus formations. The upper sandy interval (0 to $65 \mathrm{~m}$ depth) was assigned to the Lower Devonian Tadrart Formation. These early tentative interpretations are collated with the biostratigraphical results obtained in the present study.

\section{Material and methods}

Material for the present study came from collections of old palynological slides of the Moussegouda core, from 
Société Nationale Elf Aquitaine Production (SNEAP, TOTAL, Pau, France), and from new core samples collected in the Moussegouda and KW-2 core holes, provided by Dr. D. Massa. A total of twenty-five samples were analysed for this study. The rock samples were macerated by standard palynological techniques and processed in the Laboratories of Liège, Rennes and Brest. The majority of samples yielded well-preserved palynomorphs indicating a low thermal maturity. The palynologically productive sequence in the Moussegouda core drill is represented from core $2(100 \mathrm{~m})$ to core $10(233 \mathrm{~m})$ by $123 \mathrm{~m}$ of grey-greenish siltstone and mudstone, with some subordinate more sandy levels and carbonaceous horizons (Fig. 2). In core 9, at 220-221 m depth, large rounded quartz grains occurs within silty material similar to the Late Ordovician glacio-marine diamictites recorded in numerous northern Gondwana regions. Core 1, from 67 to $79 \mathrm{~m}$, is composed of micaceous siltstones, and do not produce any palynomorph. The top of the penetrated sequence, from 0 to $65 \mathrm{~m}$ is represented by a sandy interval, and was not sampled. This core material has been previously studied for palynology by Calandra (SNEAP internal report, 1964). Boron content has also been calculated from clays mineral in the samples from the Moussegouda core hole (Stévaux \& Kulbicki 1966). These authors obtained values of $25 \mathrm{ppm}$ (C9, C10) to $65 \mathrm{ppm}$ (C2-C8), which correspond to low salinity compared to values of 150 to $250 \mathrm{ppm}$, for marine waters with normal salinity, as documented in open marine Silurian clays in Algerian Sahara basins. The moderate salinity conditions are consistent with the periglacial conditions for cores 9 and 10 and with littoral to marginal marine environmental conditions, with freshwater influences, for the cores 2 to 8 interval.

The shallow stratigraphic well KW-2 penetrated about $54 \mathrm{~m}$ of grey-green shales into the Tanezzuft Formation and the sandstones of the Memouniat Formation for $7 \mathrm{~m}$ (Grignani et al. 1991). Some graptolites (Normalograptus medius) and chitinozoans were recovered in cores 2 (18 to $19 \mathrm{~m})$ and $3(30-31 \mathrm{~m})$, supporting a Late Hirnantian to early Rhuddanian age (Loydell 2012). In core 4 (36-37 m) some chitinozoans of Late Ordovician age have been previously reported (assemblage "A" of Grignani et al. 1991). These authors concluded that this lowermost portion of the "Tanezzuft" Formation (at least $18 \mathrm{~m}$ ) should therefore be assigned to the Late Ordovician. However, these chitinozoans are here included in the synonymy list of E. moussegoudaensis Paris sp. nov. and are assigned to the latest Hirnantian-earliest Rhuddanian (see discussion below).

Reference slides are stored in the palynological collections of Liège, Rennnes and Brest universities. The locations of illustrated specimens in the slides are indicated by England Finder coordinates.

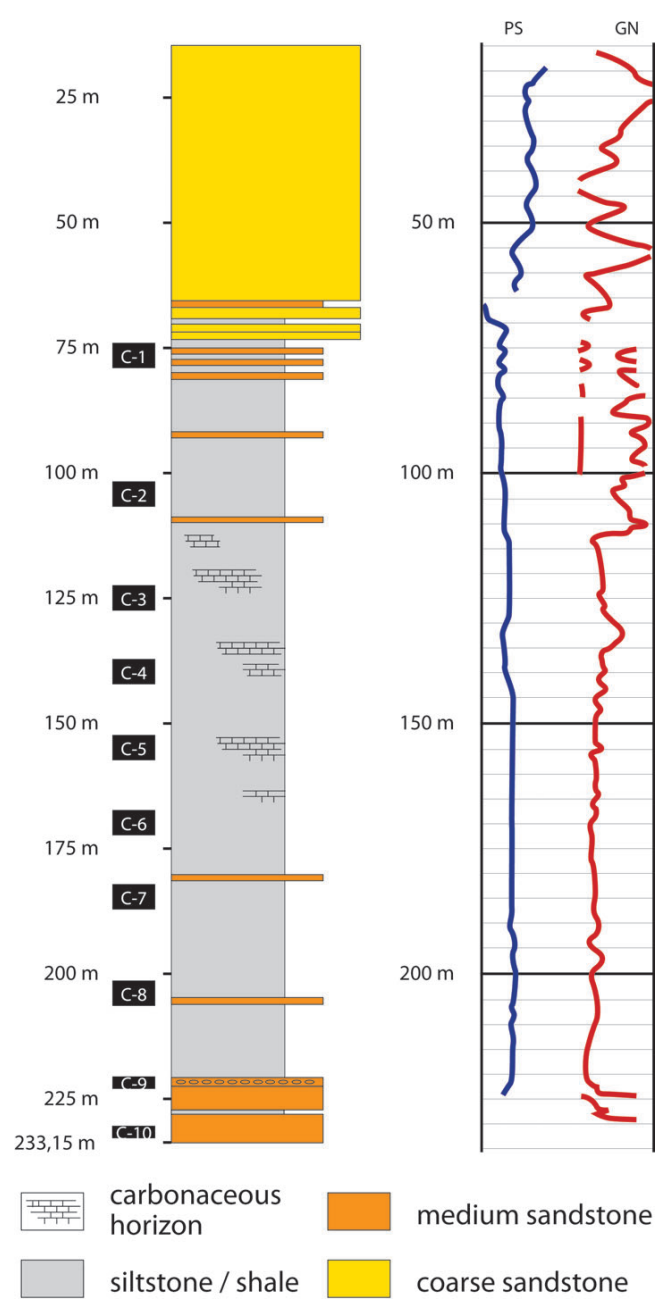

Figure. 2. Lithostratigraphy of the Moussegouda section and location of the studied core samples.

\section{Palynology}

\section{Cryptospores and plant fragments}

Abundant and well-preserved cryptospores were observed in samples ranging from 233 to $123 \mathrm{~m}$ of the Moussegouda core hole. Significant forms are illustrated in Fig. 10. In all the studied samples the miospore assemblages are very similar and consist of the following taxa: Dyadospora murusattenuata and D. murusdensa Strother \& Traverse, 1979, Pseudodyadospora petasus Wellman \& Richardson, 1993, Tetrahedraletes medinensis Strother \& Traverse, 1979, T. grayii Strother, 1991, Segestrespora laevigata Burgess, 1991, S. rugosa (Johnson) Burgess, 1991, S. membranifera (Johnson) Burgess, 1991, Rugosphaera cerebra Miller \& Eames, 1982, Velatitetras laevigata Burgess, 1991, V. rugosa Steemans et al., 1996, V. retimembrana (Miller \& Eames) Wellman \& Richardson, 1996, Rimosotetras problematica Burgess, 1991, Imperfectotriletes patinatus Steemans et al., 2000, Imperfectotriletes vavrdovae (Richardson) 
Steemans et al., 2000. Only three specimens of a true trilete spore have been observed (one in sample 150-156 m and two in sample 120-126 m). It belongs to the morphon Ambitisporites avitus-dilutus sensu Steemans et al., 1996.

\section{Chitinozoans}

Most of the chitinozoans recovered from the Moussegouda core samples are well preserved. Significant elements of the assemblage are illustrated on Figs 6 and 7. The thermal alteration is low as demonstrated by the brownish to yellowish colour of their vesicle neck. The chitinozoan abundance ranges from less than one to nine specimens per gram of rock. Such values are low when compared to the abundances usually recorded in pre-glacial Late Ordovician marine deposits from northern Gondwana localities (e.g., Bourahrouh et al. 2004, Paris et al. 2013a). However, in latest Ordovician marine strata related to the Hirnantian glaciation, low chitinozoan abundances ranging around a few specimens per gram of rock have been recorded previously (e.g., Oulebsir \& Paris 1995, Paris et al. 2000a). In the case of glacio-marine diamictites, which are regarded as resulting from the melting of icebergs originating from the Gondwanan ice cap, a dilution effect can be invoked to explain such low chitinozoan abundances. Indeed, rapid sedimentation occurred due to a large amount of detritical material available (i.e. composed of clay, "glacial flour", and dropstones of various size and origin), and to an important accommodation space available and resulting from a rapid rise of the sea-level subsequently to the melting of the ice cap.

\section{Organic-walled microphytoplanktonic elements and miscellaneous organic debris}

The organic residues contain also well-preserved acritarchs, various microalgal remains such as prasinophycean phycomata (e.g. Tasmanites and leiospheres), few scolecodonts, fragments of eurypterids and miscellaneous organic debris. The most important elements in the assemblages are illustrated in Figs 8 and 9. The majority of acritarchs are considered to be cysts of marine phytoplanktonic algae (Martin 1993, Le Hérissé et al. 2009). They are never abundant in this material, with an average value of $5 \%$ of all palynomorphs. The prasinophycean algae are a class of green algae, represented in the deposits by their phycomata (Tappan 1980, Colbath \& Grenfell 1995, Guy-Ohlson 1996). They dominate the marine fraction, reaching an average proportion of $80 \%$ of all palynomorphs, throughout the section, with exception of the base of core 8 . They are well represented herein by abundant leiospheres of various sizes and by tasmanitids. Other palynomorphs suggesting a transitional marine-freshwater environment, are represented by colonies of Gloeocapsomorpha (Fig. 9N, O), specimens of Moyeria and Clypeolus and cuticular fragments of eurypterids (Fig. 9P, Q).

In a few samples, some enigmatic sac-like microfossils, sub-spherical or ovoid, with a pigmented wall and a striate mesh-like ornamentation, generally only developed at one pole (Fig. 9I, J, K), have also been recovered. They could be some metazoan remains. They recall sac-like fossils assigned to cocoons (egg-cases) of clitellate annelid as illustrated by Manum et al. (1991). The fossil record of these mesofossils is presently restricted to the Mesozoic and Neogene (see Manum et al. 1991, Manum 1996, Jansson et al. 2008). They have never been mentioned in the Palaeozoic, and their occurrence in the Moussegouda material is related to very specific palaeoenvironmental conditions, with freshwater and terrestrial inputs.

Significant fluctuations in abundance and diversity of broad groups within the palynomorph assemblages are likely to have reflected environmental changes.

The acritarch diversity remains low through the section. The acritarchs comprise a total of 24 species, and many are simple spiny acritarchs (acanthomorphs) referred to Dorsennidium, Micrhystridium, Multiplicisphaeridium, Veryhachium or Villosacapsula, and netromorphs referred to Dactylofusa and Eupoikilofusa. More diagnostic Late Ordovician species of Neoveryhachium, Saharidia or Tunisphaeridium are also encountered in the base of the studied interval. The low abundance and diversity of the acritarchs is attributed to the nearshore environmental conditions. By comparison the Leiosphaeridia that we assigned to prasinophycean phycomata are abundant. Tasmanites are represented both by simple or ornamented forms. The new described species, Tasmanites tzadiaensis nov. sp., has a characteristic ornamention made of low solid verrucae ( $c f$. systematic part).

The palynomorph Moyeria cabottii (Cramer) Miller \& Eames 1982, never abundant, is known from the base of the core hole, and is sporadically present throughout the section. It is diversely interpreted in the literature, either as a terrestrial or freshwater acritarch (Dorning \& Harding 1998), or as a possible euglenoid inhabiting freshwater terrestrial environment (Gray \& Boucot 1988). A plant origin is even envisaged (Wellman \& Richardson 1993, Richardson 1996). In agreement with Dorning \& Harding (1988), we consider that they are probably freshwater aquatic forms. As for the cryptospores, their occurrence in the material resulted from periodic terrestrial inputs into a marginal marine environment. Some Clypeolus, with possible affinity to the zygnemataceae (Miller et al. 1997) are also present.

Gloeocapsomorpha prisca Zalessky, 1917, emend. Foster, Reed \& Wicander, 1989, is common in several samples. Gloeocapsomorpha prisca is an enigmatic palynomorph whose biological affinity is still debated. Foster et al. (1989, 1990) suggested they must have been 
Figure 3. Distribution and absolute abundances of chitinozoan species in the Moussegouda core hole. Abbreviations: $>50 \%, \bullet-20-50 \%$, ○ $-10-20 \%, \Delta-0-10 \%$.

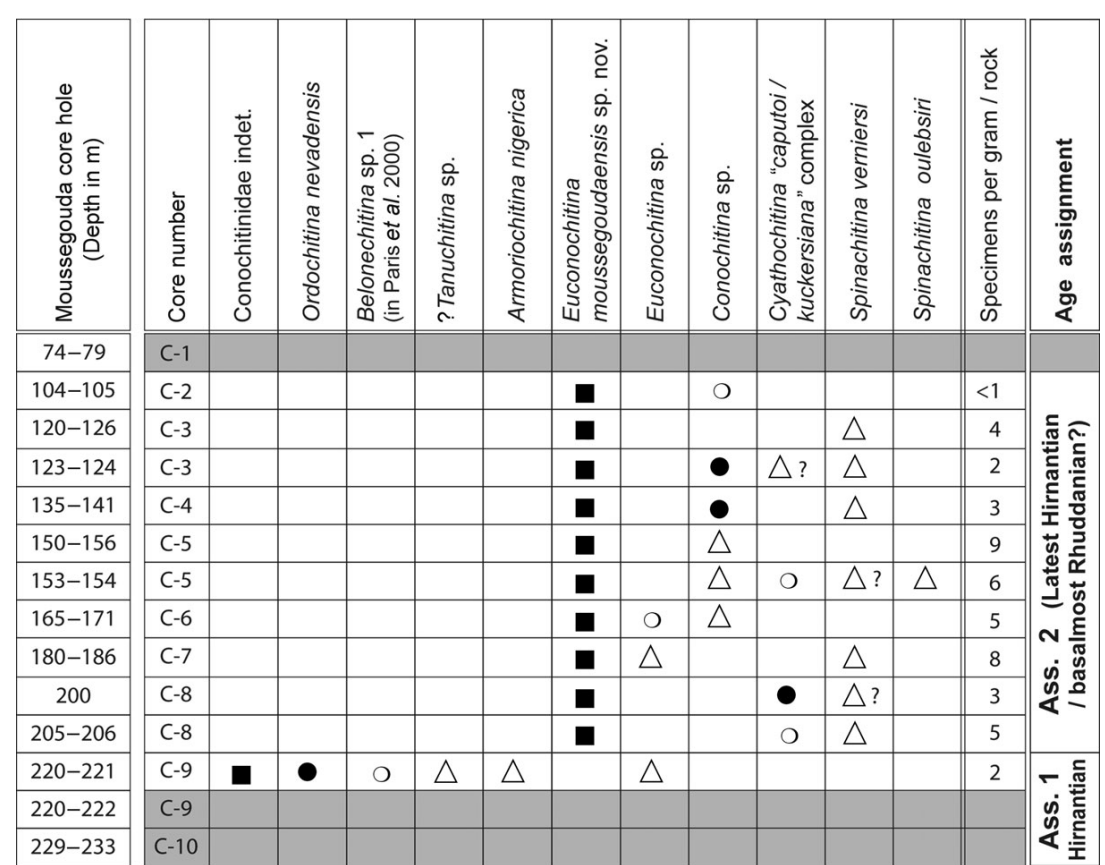

mat-forming cyanobacteria similar to Enthophysalis major from an intertidal environment. Derenne et al. (1990, 1992) suggested they were preserved algaenan cell walls of green algae like Botryococcus braunii. The colonies of G. prisca can be abundant in oil-prone source rocks, such as Ordovician kukersites (Blokker et al. 2001), but also in the late Devonian (Fowler et al. 2004).

Fragments of invertebrates, mainly referred herein to eurypterids are known in the interval C4 to C9. Fragments consist of chitinous pieces of exoskeletons such as cuticles and spines. Organic-walled invertebrate remains are reported from Cambrian to Carboniferous strata (Miller 1996). In northern Gondwana, they are fairly common in latest Ordovician and in Silurian nearshore deposits.

\section{Biostratigraphy}

\section{Cryptospores}

Most of the cryptospore species identified in the Moussegouda samples are typical of the interval ranging from the Katian to Llandovery (Edwards \& Wellman 2001). Such assemblages are known from South America in Brazil and Paraguay (Gray 1991; Gray et al. 1985, 1992; Laranjeira et al. 1997; Melo 1997; Melo \& Steemans 1997; Mizusaki et al. 1992; Steemans 2000; Steemans \& Pereira 2000), from North America (Strother \& Traverse 1979, Miller \& Eames 1982, Duffield 1985, Johnson 1985), from Europe in Belgium (Steemans 2001), Bulgaria (Lakova et al. 1992), the Czech Republic (Vavrdová 1984, 1988, 1989), United Kingdom (Burgess 1991, Wellman 1996), from Asia in
China (Wang et al. 1997), Turkey (Steemans et al. 1996), Saudi Arabia (Steemans et al. 2000, Wellman et al. 2000), and from north Africa in Libya (Richardson 1988).

There is only very limited palynostratigraphic evidence based on miospores to distinguish Late Ordovician from earliest Silurian miospore assemblages. The miospore biostratigraphy across the Ordovician-Silurian boundary has been revised by Steemans et al. (2000). The main criteria include the first occurrence and proliferation of true trilete spores (Ambitisporites avitus morphon sensu Steemans et al. 1996), the first occurrence of L. divellomedia, and the progressive decline of cryptospores enclosed in a membranous envelope. The assemblage herein observed is characterised by very rare true trilete spores, by a high abundance of cryptospores enclosed in an outer envelope, by numerous specimens of Imperfectotriletes and by the absence of L. divellomedia. Accordingly, this assemblage can be attributed to Sub-zone $\beta$ of the Imperfectotriletes Interval Biozone (Steemans 2000). The possible age for this biozone has a maximum range from Hirnantian to early Aeronian, but most probably not younger than Rhuddanian because of the absence of L. divellomedia.

\section{Chitinozoans}

Two chitinozoan assemblages are identified in the Moussegouda core material. The first one is restricted to core 9 (sample from depth 200-221 m). The second extends from core 8 to core 2 , i.e. ranging at least over $102 \mathrm{~m}$. These two chitinozoan assemblages are very different (Fig. 3). 
Assemblage 1 is dominated by undetermined Conochitinidae (50\%). Several species are grouped under this name. However, the preservation is too poor in this sample to allow even a generic assignment (broken vesicles, eroded spines, possibly related to reworking processes). Ordochitina nevadensis Soufiane \& Achab (see Fig. 7A1, 2, G, H) (30\%) and to a lesser extent, Belonechitina sp. 1 (sensu Paris et al. 2000b) (11\%) are also well represented (Fig. 3). The subordinate taxa are Armoricochitina nigerica (5\%), Euconochitina sp. (3\%) and a form possibly belonging to Tanuchitina $(<2 \%)$. SEM observations were necessary to identify the fragments of $A$. nigerica, which may be reworked. This chitinozoan material, especially $O$. nevadensis, and A. nigerica, clearly documents the occurrence of Late Ordovician marine deposits in the lowermost part of Moussegouda core hole.

Assemblage 2 is largely dominated by Euconochitina moussegoudaensis Paris sp. nov. (Figs 6A, B, I, J, 7D). The relative frequency of this new species (see description below) ranges from $60 \%$ to more than $90 \%$ of the recorded taxa. Among the associated taxa is Spinachitina verniersi Vandenbroucke (Figs EI-2, G, H, 6C), which seems identical to the specimens previously identified as Spinachitina sp. aff. oulebsiri by Paris et al. (2000a, pl. 1, figs 1 and 4) in well Nl-2 (north-eastern Algerian Sahara), from the M'Kratta Formation. Spinachitina oulebsiri Paris et al. (Fig. 6K) is represented by a single specimen, recorded in core 5 at $153-154 \mathrm{~m}$ depth. Various Cyathochitina forms occur in Assemblage 2. Some specimens (Fig. 7F) are very close to Cyathochitina caputoi Da Costa; others have a wide carina and a more elongate neck (Fig. 7E), and thus recall $C$. kuckersiana (Eisenack). However, because the large morphological variations observed in the Moussegouda material, all the recorded forms are provisionally grouped within a "caputoi-kuckersiana complex" (Fig. 3). The relative frequency of Cyathochitina species is highly variable. It reaches $36 \%$ in core 8 , and $11 \%$ in core 5 where only forms very similar to $C$. caputoi have been observed. Euconochitina sp. (restricted to cores 6 and 7) and Conochitina sp., which is better represented in cores 3 and 4, are the other components of Assemblage 2.

The Late Ordovician chitinozoan data available from Baltica (Nõlvak 1999, Nõlvak \& Grahn 1993) and from eastern Laurentia (Achab 1978, 1981; Soufiane \& Achab 2000a) do not allow precise correlation with the chitinozoan assemblages from northern Gondwana. Surprisingly, some ties exist with chitinozoan assemblages from western and northern Laurentia. The best correlation is provided by Ordochitina nevadensis. Soufiane \& Achab (2000b, figs 2 and 3) reported this species from the uppermost Vinini Formation and from the Hanson Creek Formation, in Nevada. These authors (2000b, fig. 4) also report $O$. nevadensis from the $O$. fastigatus and $P$. pacificus graptolite zones in the lower part of the Cape Phillips For- mation (Arctic Canada), i.e. Katian (formerly Ashgill proparte). In Nevada, however, this species clearly extends within the $N$. persculptus graptolite Zone. This means that the last appearance datum (LAD) of $O$. nevadensis is in the late Hirnantian, i.e. after the $\delta^{13} \mathrm{C}$ excursion and after the eustatic sea level fall in Nevada (see Finney et al. 1999, fig. 2). Thus, based on the well-documented range of $O$. nevadensis in the uppermost part of the Vinini Formation (Soufiane \& Achab 2000b, fig. 3), Assemblage 1 from Moussegouda may be as young as the late Hirnantian. This is in agreement with the presence of Armoricochitina nigerica in our Assemblage 1, because this Late Ordovician species (Paris 1990) has also its LAD in the latest Hirnantian (Paris et al. 2000a, Bourahrouh 2002). The absence of the other usual components of the Gondwanan Hirnantian chitinozoan species (e.g., Tanuchitina elongata, Calpichitina lenticularis) or of Laurentian (e.g., N. vininica) in core 9 of Moussegouda core hole, however, must be stressed.

Belonechitina sp. 1 (Fig. 7B, C) is another taxon from our Assemblage 1. In northern Gondwana, an exclusive occurrence of Belonechitina sp. 1 has been documented in Saudi Arabia, in the upper part of the Quwarah Member of the Qasim Formation (well Ain Dar-196, core 24), some $50 \mathrm{~m}$ below strata referred to the Sarah Formation, and possibly within the Sarah Formation (well Shedgum-239, core 8; see Paris et al. 2000b). The Sarah Formation was regarded as "latest Asghill-earliest Silurian" in age (Al Hajri \& Owens 2000), but recent palynological data (Paris et al. 2013a in press) indicate that this formation does not range beyond the top of the Hirnantian.

Other data from well Nl-2, located in north-eastern Algerian Sahara, strongly suggest that Assemblage 2 recorded in cores 2 to 8 in Moussegouda is of latest Hirnantian and possibly basalmost Rhuddanian age. Indeed, in well Nl-2, cores 29 and 30 from the upper part of the M'Kratta Formation yield a chitinozoan assemblage representative of the Spinachitina oulebsiri biozone, including the index species itself, but also Spinachitina verniersi, a species recently described by Vandenbroucke et al. (2009) in the Soom shale, in South Africa. This species is identical to the specimens recorded in Moussegouda (Fig. 6C, G, H). In Algerian Sahara, before an exclusive occurrence in the upper part of the M'Kratta Formation (marine post-glacial deposits), these two taxa are briefly associated with classical components of the chitinozoan assemblages from the Hirnantian glacio-marine diamictites of the Hassi el Hadjar Formation (i.e., T. elongata, $C$. lenticularis, E. lepta, A. nigerica; see Oulebsir \& Paris 1995, Paris et al. 2000a, Videt et al. 2010). However, in the M'Kratta Formation, reworking processes cannot be excluded as the preservation of these species is poor with regard to those of $S$. oulebsiri and $S$. verniersi (provisionally identified as $S$. sp. aff. oulebsiri in Paris et al. 2000a). The 


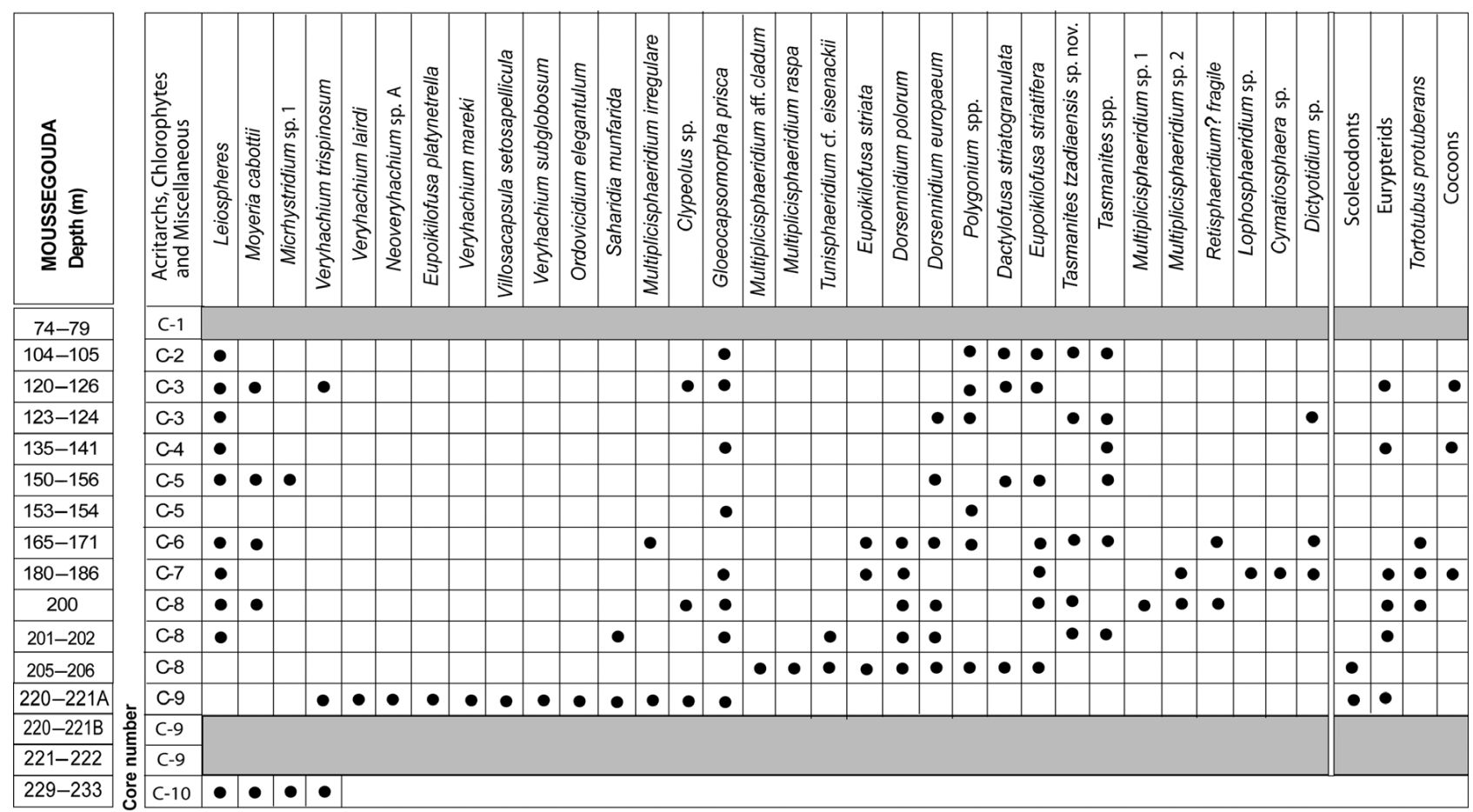

Figure 4. Distribution of organic-walled microphytoplanktonic elements and Miscellanea in the Moussegouda core hole.

absence of the former listed Late Ordovician taxa in Assemblage 2 of Moussegouda is in favour of an age slightly younger than in N1-2. This is also consistent with sporadic occurrences of Cyathochitina e.g. caputoi (Fig. 7F) in the Moussegouda material because this species may be abundant in the Early Rhuddanian black shale and "hot shale" in Saharan and Arabian localities (see discussion of the range of C. caputoi in Paris et al. 2013a, b, and Thusu et al. 2013). If one accepts that the FAD of Spinachitina fragilis coincides with the base of the Rhuddanian as documented by Bourahrouh (2002) in Bohemia and in the Armorican Massif, then the age of Assemblage 2 from Moussegouda is bracketed between the late Hirnantian and the early Rhuddanian. In the present case, the duration of the corresponding time slice (in the range of a few ten thousand years) is obviously beyond the limits of the power of resolution of the chitinozoans. Similar situations are reported elsewhere in southern Sahara for the graptolites around the Ordovician-Silurian boundary, and Legrand (2009) used the term "post perscultus-pre ascensus" graptolite fauna for this time interval. Consequently, we propose a latest Hirnantian age assignment for cores 2 to 8 in Moussegouda, but an earliest Rhuddanian age (i.e., pre-fragilis chitinozoan biozone) cannot be definitively excluded.

Further north, in southern Libya (Kufra Basin, Fig. 1), Grignani et al. (1991) have defined three palynozones, "A", "B" and "C". In the KW-2 shallow core drill, they recognise two chitinozoan assemblages, with respectively an assemblage " $A$ " from core 4 (36-37 $\mathrm{m})$ and an assemblage
"C" from cuttings $(27 \mathrm{~m})$. In their assemblage " $\mathrm{A}$ ", Grignani et al. (1991) recorded a dominating form they identified as Conochitina chydaea Jenkins. Based on recent SEM observation of this material made by one of us (F.P.) we consider part of these chitinozoans (see Fig. 7D1, 2) as conspecific with Euconochitina moussegoudaensis sp. nov. from Moussegouda. The other part (Fig. 6D, E1, 2) is identical to Spinachitina verniersi. Grignani et al. (1991, p. 1167; pl. 1, figs 9 and 10) already noticed and illustrated these forms with minute spines on the margin. Consequently, Assemblage 2 from Moussegouda and assemblage "A" sensu Grignani et al. (1991) from KW-2 must be regarded as equivalent and thus are of the same age. In $\mathrm{KW}-2$, the early Silurian graptolites from cores 2 (18-19 $\mathrm{m})$ and $3(30-31 \mathrm{~m})$ reported by Grignani et al. (1991, p. 1164; see also note on this graptolite by Loydell 2012) and the early Llandovery chitinozoans from $27 \mathrm{~m}$, does not infirm the late Hirnantian-basalmost Rhuddanian age of our Assemblage 2. It is worthy to note that another chitinozoan assemblage reported by Grignani et al. (1991) in wells A1-NC 43 (core 3, and cuttings from 1735 to $1763 \mathrm{~m}$ ) and B1-NC 43 (core 5), and called assemblage "B" by these authors, contains typical A. nigerica. It is therefore of late Katian-Hirnantian age and close to our Assemblage 1 from Moussegouda. As a consequence, assemblage " $\mathrm{B}$ " of Grignani et al. (1991) should be older than their assemblage "A" from KW-2. The corresponding deposits should not be regarded as "classical" Tanezzuft Formation but more likely as representative of the Memouniat Formation. 


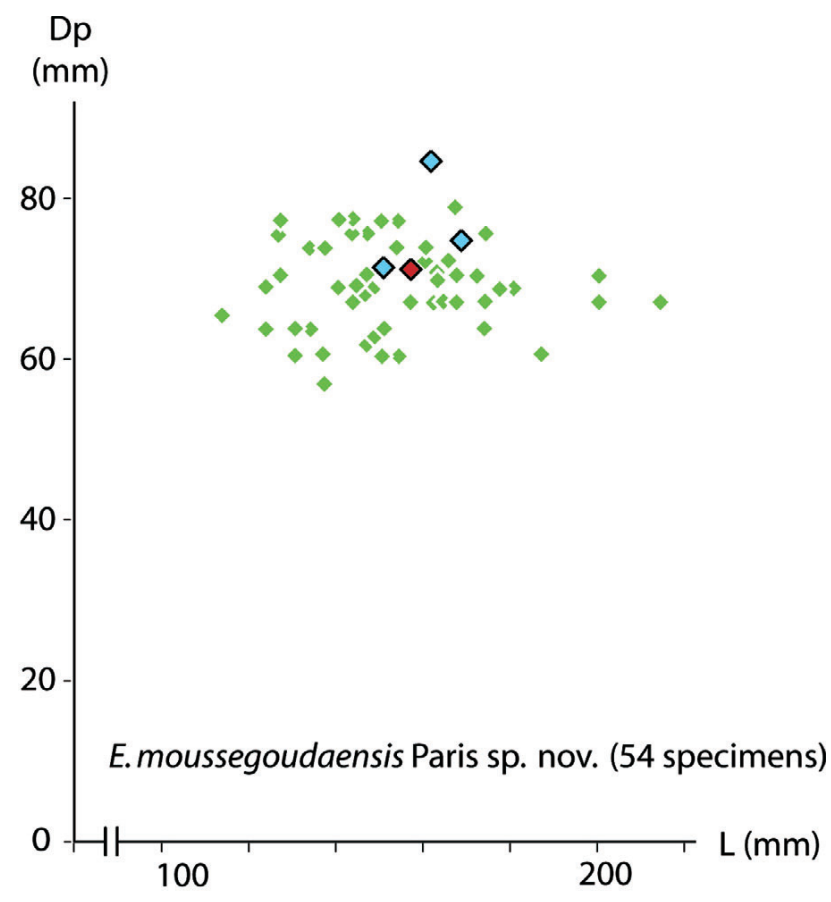

Figure 5. Biometric evaluation of Euconochitina moussegoudaensis Paris sp. nov. with the chamber diameter (Dp) plotted against the vesicle length (L). This type material (red diamond: holotype from $123 \mathrm{~m}$ depth; blue diamonds: paratypes from 153 and $205 \mathrm{~m}$ depth) from the Moussegouda core is compared to a population of 50 specimens (green diamonds) from the JA-2 shallow core at $48.18 \mathrm{~m}$ depth (Kufra Basin, Libya; see Thusu et al. 2013 in press).

During the Late Ordovician, in northern Chad and in southeast Libya, the palaeogeographical, and palaeoenvironmental situations were fairly close to those of southeastern Mauritania (e.g., Nseirat section, Hodh region, Paris et al. 1998). Both areas were located in a proximal position with regard to the Hirnantian inlandsis, and were temporary covered by the ice cap (see Ghienne 2003 and Monod et al. 2003 for references). They registered a ma- rine sedimentation overlaying glacial and /or glacio-marine diamicites. As far as chitinozoans are concerned, both localities yield post-elongata, but pre-fragilis chitinozoan assemblages (Paris et al. 1998) suggesting the existence of temporary marine excursions in depressed areas related to isostatic processes. The lack of Silurian black shale in northern Chad and south-eastern Libya, and the truncated early Llandovery sequence in south-eastern Mauritania are likely related to the isostatic readjustment that rapidly starved the marine sedimentation in the areas previously overlain by a thick ice cover.

\section{Microphytoplankton}

Based on the composition of assemblages of organicwalled microphytoplanktonic elements, the stratigraphic section can be subdivided into two distinct assemblages which are described in ascending stratigraphic order: a lower unit with the deepest samples of cores 10 and 9 , and an upper unit from cores 8 to 1 .

The basal assemblage is only defined from two samples (229-233 and 220-221A m) of cores 10 and 9. Particularly noteworthy are the following species present in core 9: Eupoikilofusa platynetrella, Neoveryhachium sp. A, Ordovicidium elegantulum probably reworked, Saharidia munfarida, Veryhachium mareki, Veryhachium subglobosum, and Villosacapsula setosapellicula.

The association of Eupoikilofusa platynetrella, Saharidia munfarida, Veryhachium mareki and Veryhachium subglobosum, is diagnostic of the late Ordovician (Hirnantian) acritarch microflora, in glacial to periglacial successions of many localities around the margin of Gondwana (Vecoli \& Le Hérissé 2004), even thought Veryhachium mareki is also known in the preglacial sediments of the Králův Dvůr Formation in Bohemia (Vavrdová 1989). The original material of Eupoikilofusa platynetrella

Figure 6. Chitinozoans from the Upper Ordovician of northern Chad and south-eastern Libya. The specimens are housed in the University of Rennes I (France) under the repository numbers IGR 58089 to 58099 . The England-Finder coordinates are in brackets. The scale bar represents 100 micrometers on Figs A1, B-E1, F, I, J1, and K, and 10 micrometers on Figs A2, E2, G, H and J2. - A1, 2 - Euconochitina moussegoudaensis Paris sp. nov., Moussegouda core hole (northern Chad), core 8, 205-206 m; A1 - paratype, flattened vesicle, IGR 58092 (Q39), A2 - detail of the granular wall surface. - B - Euconochitina moussegoudaensis Paris sp. nov., Moussegouda core hole (northern Chad), core 8, $205-206$ m, IGR 58092 (R39). Short paratype. - C - Spinachitina verniersi Vandenbroucke in Vandenbroucke et al., 2009, Moussegouda core hole (northern Chad), core 3, $123-124$ m, IGR 58094 (R39/1). Note the eroded spines on the margin. • D - Spinachitina verniersi Vandenbroucke in Vandenbroucke et al., 2009, KW-2 core drill (Jebel Asba, Kufra Basin, south-eastern Libya), 34-36 m. • EI-2 - Spinachitina verniersi Vandenbroucke in Vandenbroucke et al., 2009, KW-2 core drill (Jebel Asba, Kufra Basin, south-eastern Libya), 34-36 m. Note the tiny spinose ornamentation on the margin of the specimens on D and E2. $\bullet$ F - Euconochitina sp. aff. moussegoudaensis Paris sp. nov., Moussegouda core hole (northern Chad), core 3, 123-124 m, IGR 58094 (P38). Slender vesicle with granular surface. - G - Spinachitina verniersi Vandenbroucke in Vandenbroucke et al., 2009, Moussegouda core hole (northern Chad), core 8, 205-206 m, IGR 58092 (O40/3); detail of the margin showing eroded lambda spines. $\bullet \mathrm{H}$ - Spinachitina verniersi Vandenbroucke in Vandenbroucke et al., 2009, Moussegouda core hole (northern Chad), core 8, 200 m, IGR 58091 (?P38/1); detail of the margin showing closely spaced lambda minute spines. • I - Euconochitina moussegoudaensis Paris sp. nov., Moussegouda core hole (northern Chad), core 5, 153-154 m, IGR 58093 (U40/4). Paratype. • J1-2 - Euconochitina moussegoudaensis Paris sp. nov., Moussegouda core hole (northern Chad), core 3, 123-124 m; J1 - holotype, IGR 58094 (040), with a close up of the margin (J2). • K - Spinachitina oulebsiri Paris et al., 2000a, Moussegouda core hole (northern Chad), core 5, 153-154 m, IGR 58093 (R38/2); note the conical spines on the margin. 
Alain Le Hérissé et al. • Late Ordovician-earliest Silurian palynomorphs from northern Chad
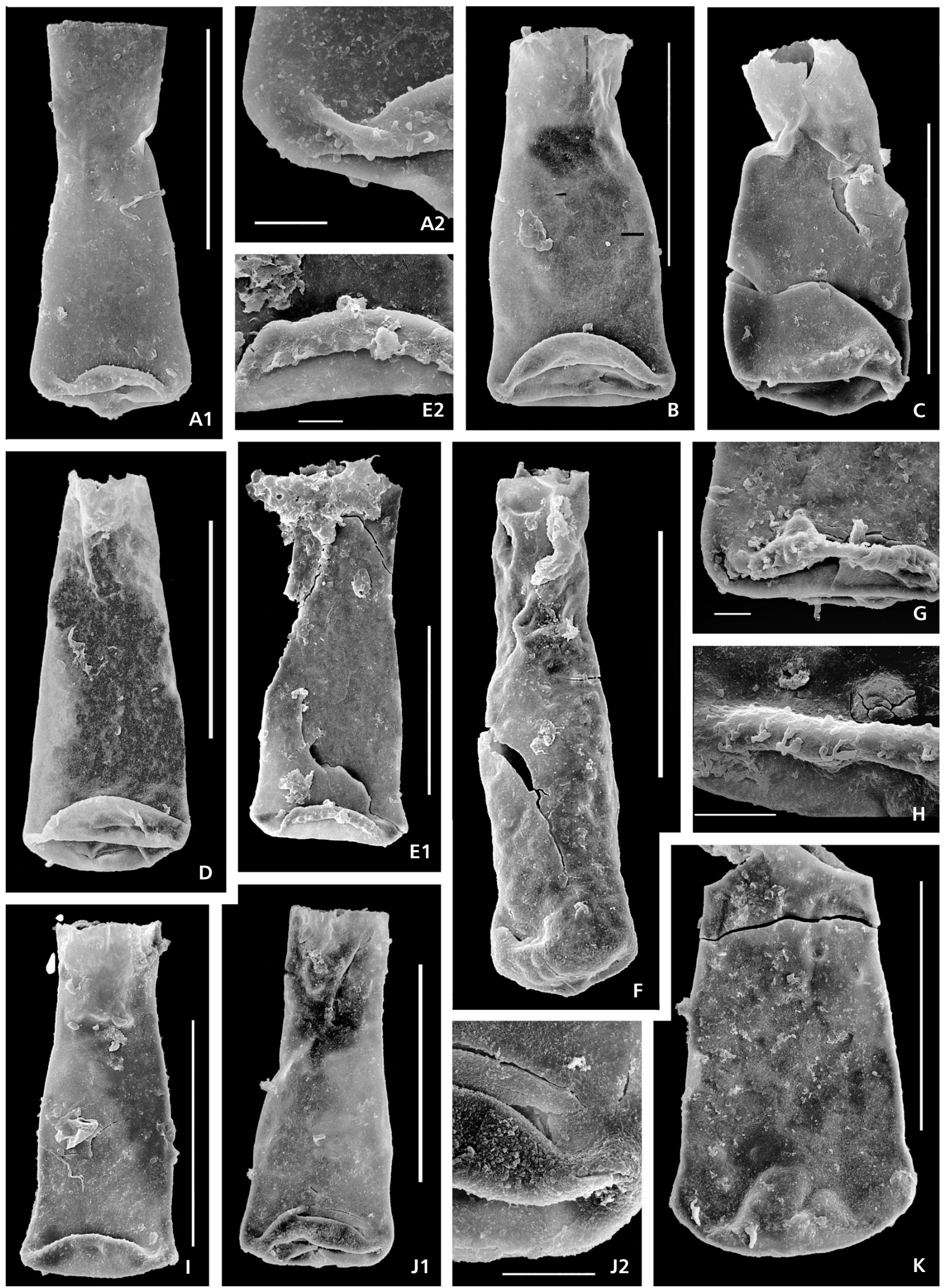
comes from the Upper Ordovician of U.S.A (Loeblich \& Tappan 1978). Saharidia munfarida is an interesting component of the interval with diamictites of the Late Ordovician Kosov Formation in Bohemia (Vavrdová 1982). Occurences of Eupoikilofusa platynetrella and Saharidia munfarida established in the microconglomeratic clays of the Hassi el Hadjar Formation of wells Nl-2 and Gd-1bis in Algeria (Vecoli 1999, Le Hérissé et al. 2003), and coeval Tifarouine Formation of the Tazzeka succession in Morocco, close to the Ordovician-Silurian boundary (Le Hérissé, unpublished data). In well Nl-2, Saharidia munfarida persist in the M'Kratta Formation post dating the ice cap melting, assigned to the late Hirnantian (Le Hérissé, unpublished data). In the Moussegouda core rare specimens have also been encountered in the basal part of the succeeding assemblage. Saharidia munfarida is also mentioned, but not illustrated, in the uppermost Djeffara Formation, of latest Ordovician age, in the Ghadames Basin, Tunisia (Vecoli et al. 2009). These elements allow cores 10 and 9 from Moussegouda to be correlated with late Hirnantian strata. This is consistent with the occurrence of few reworked specimens, e.g. Ordovicidium elegantulum in core $9(220-221 \mathrm{~m})$. The occurrence of reworked elements of older strata is a characteristic of the late Ordovician, during the deglacial period or related to final isostatic movements (Vecoli \& Le Hérissé 2004).

The basal assemblage includes also Villosacapsula setosapellicula. The last specimens are observed in basal part of the succeeding assemblage, in situ or possibly reworked. The species Villosacapsula setosapellicula has a long stratigraphical range, from Dariwillian to Hirnantian (see discussion of occurrences in Wicander \& Playford 2007), but is more common in the Katian (Asghill pro parte), e.g. in the Sylvan Shale of Oklahoma (Loeblich 1970), in north-east Libya (Molyneux \& Paris 1985), and particularly in the Hirnantian (Vecoli \& Le Hérissé 2004). This species, associated to Veyhachium subglobosum is present in assemblage "B" of Grignani et al. (1991), described in the Kufra Basin, southern Libya, and here reattributed to the Hirnantian (see the discussion for chitinozans).
Comparing this Upper Ordovician acritarch and prasinophyte assemblage in the basal unit of Moussegouda, with published correlative assemblages, particularly from North Africa (e.g. Algeria, Morocco, Libya), or Bohemia, highlights the absence of several diagnostic species such as Beromia clipeata, Dactylofusa cucurbita, Oppilatala cf. frondis etc., and a low percentage of reworked elements. This suggests (1) a possible palaeoecological control on the distribution of these species, or (2) that the interval represents the end of synglacial units, equivalent to part of the M'Kratta Formation in well Nl-2 (north-eastern Algerian Sahara). In southern Libya (Kufra Basin), Grignani et al. (1991) reported Dactylofusa cucurbita, Veryhachium subglobosum etc., in their assemblage " $\mathrm{B}$ ", which is comparable to our first assemblage in the basal unit from Moussegouda. This is also consistent with the results on chitinozoans.

The second assemblage is recorded from 11 samples of core 8 to 2 (between 205-206 m and 104-105 m). It is significantly different from the preceding assemblage, within which many characteristic taxa are replaced by forms such as Multiplicisphaeridium aff. cladum, Multiplicisphaeridium raspa, Eupoikilofusa striata, Dorsennidium polorum, Dactylofusa striatogranulata, Eupoikilofusa striatifera or Tasmanites tzadiaensis Le Hérissé nov. sp. However, the species turnover is not total because two classical Upper Ordovician species, Saharida munfarida and Villosacapsula setosapellicula, which occur earlier, range into the base of the second assemblage.

The assemblage is of moderate diversity, with a dominance of Tasmanites and leiospheres, of netromorphs and quite simple acanthomorphic acritarchs. Latitudinal and inshore-offshore trends have been mentioned in the studies of Lower Palaeozoic microphytoplankton (see synthesis in Mullins et al. 2004). Changes in microphytoplankton associations for determining nearshore to offshore trends, globally suggest a low diversity microflora comprising abundant simple sphaeromorphs and tasmanitids in nearshore environments, while open marine environments yield a highly diversified microflora (e.g., Jacobson 1979, Dorning 1981, Al-Ameri 1983, Vecoli 2000). Littoral to

Figure 7. Chitinozoans from the Upper Ordovician of northern Chad (A-C, E-H) and south-eastern Libya (D). The specimens are housed in the University of Rennes I (France) under the repository numbers IGR 58089 to 58099 . The England-Finder coordinates are in brackets. The scale bar represents 100 micrometers on A1, B1-D1, E-H, and 10 micrometers on A2, B2 and D2. • A1, 2 - Ordochitina nevadensis Soufiane \& Achab, 2000b, Moussegouda core hole (northern Chad), core 9, 220-221 m; A1 - flattened and folded vesicle, IGR 58099 (N45/4), A2 - detail of the closely spaced lambda spines arranged in vertical rows. $\bullet$ B1, 2 - Belonechitina sp. 1 (in Paris et al., 2000b), Moussegouda core hole (northern Chad), core 9, 220-221 m; B1 - damaged flattened vesicle, IGR 58099 (P43/4), B2 - detail of the ornamentation showing preserved spines. • C - Belonechitina sp. 1 (in Paris et al., 2000b), Moussegouda core hole (northern Chad), core 9, 220-221 m, IGR 58099 (P42/4). Note the large broken spines. • D1, 2 - Euconochitina moussegoudaensis Paris sp. nov., KW-2 core hole (Jebel Asba, Kufra Basin, south-eastern Libya), 34-36 m; D1 - flattened vesicle, D2 - detail of the finely granular surface. • E - Cyathochitina e.g. kuckersiana (Eisenack, 1931), Moussegouda core hole (northern Chad), core 8, 200 m; IGR 58091 (R41/2), broken specimen showing the collapsing of the vesicle during flattening process. $\bullet \mathrm{F}-$ Cyathochitina e.g. caputoi Da Costa, 1971 , Moussegouda core hole (northern Chad), core 5, 153-154 m, IGR 58093 (R39/2). • G - Ordochitina nevadensis Soufiane \& Achab, 2000b, Moussegouda core hole (northern Chad), core 9, 220-221 m, IGR 58099 (P46/4). • H - Ordochitina nevadensis Soufiane \& Achab, 2000b, Moussegouda core hole (northern Chad), core 9, 220-221 m, IGR 58099 (P47). 

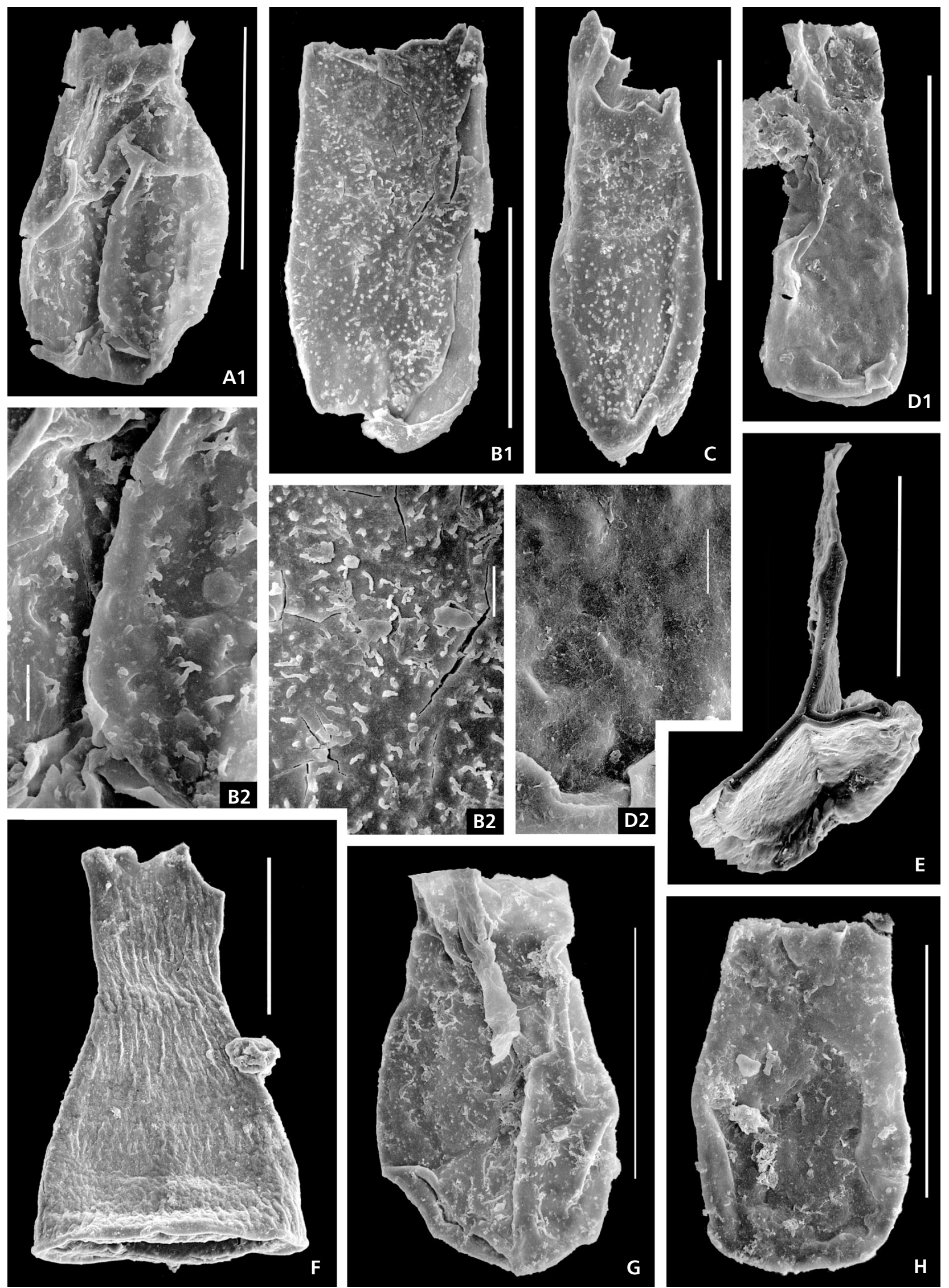

D2
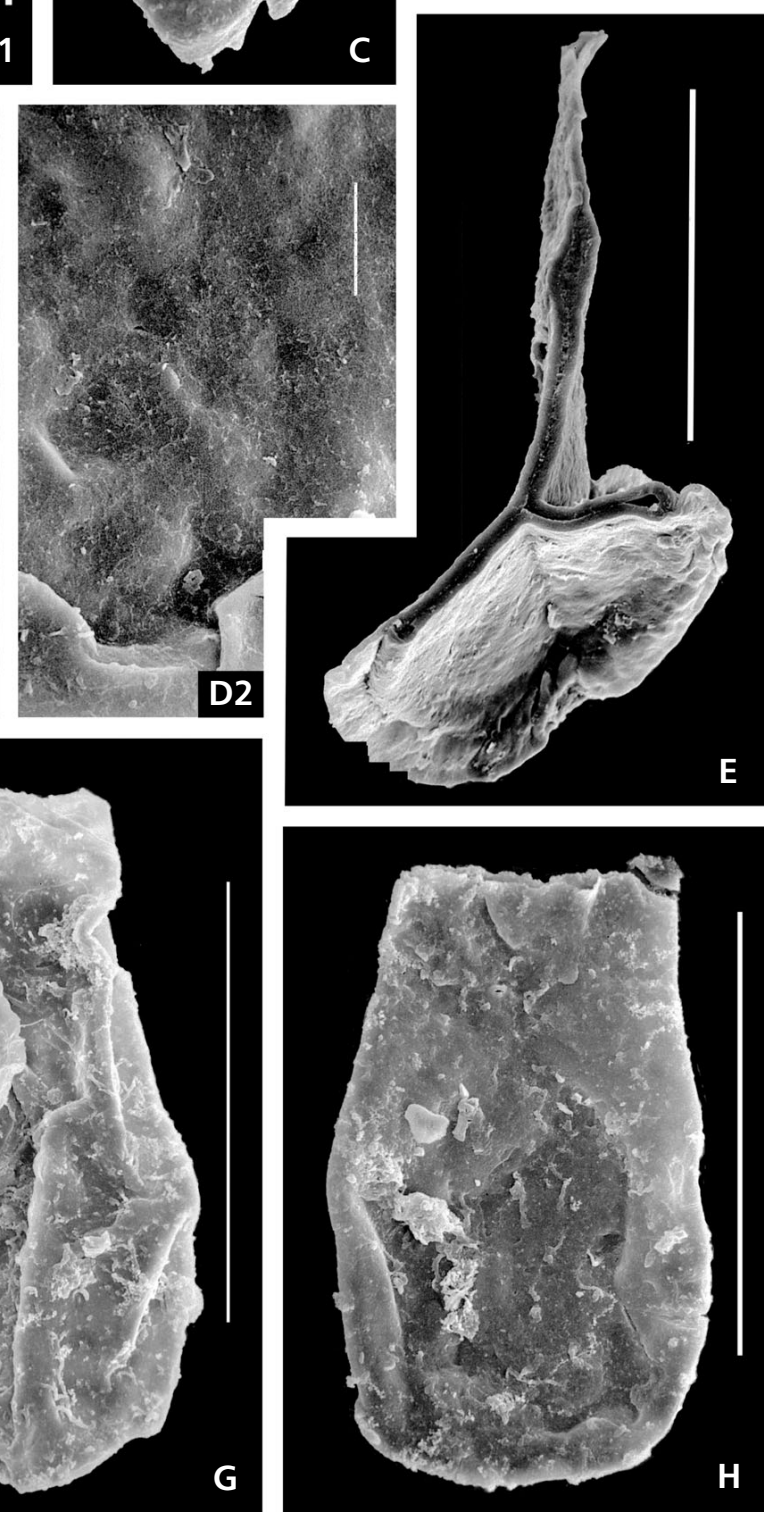
nearshore conditions for the association are proposed in the second assemblage of Moussegouda, but also in the samples from KW-2 in the Kufra Basin, is consistent with significant freshwater input. This is supported by the presence of forms such as Moyeria cabottii regarded to be of freshwater origin (Gray \& Boucot 1989, Dorning \& Harding 1998). The good representation of miospores, and tubular structures (Tortotubus protuberans) believed to derive from nematophytes (Wellman 1995), is further evidence of deposition in a nearshore shallow water marine environment.

The recovered assemblage contains species with a restricted stratigraphic range, making them useful for biostratigraphic correlation such as Dactylofusa striatogranulata. Previous records of Dactylofusa striatogranulata, with exclusion of specimens misidentified in the literature, occur in the Upper Ordovician and early Silurian of Algeria, zones F and G1 (Jardiné et al. 1974), in the Upper Ordovician of Algeria and Tunisia (Vecoli 1999), the Czech Republic (Vavrdová 1988, 1989), in well Nl-2 (north-eastern Algerian Sahara) from the middle part of Hassi El Hadjar Formation and in the M'Kratta Formation, in preglacial and post-glacial Hirnantian sediments (Le Hérissé et al. 2003, Le Hérissé unpublished data), and in the Hirnantian in Turkey (Le Hérissé in Paris et al. 2007). The assemblage is also well characterized by Tasmanites tzadiaensis Le Hérissé nov. sp. This species has also been encountered in core material from the Jebel Asba area of the Kufra Basin, in post-glacial deposits of latest Hirnantian or earliest Rhuddanian age (Thusu et al. 2013 in press). It could represent a fossil guide for the nearshore environments represented in southeastern Libya (Kufra Basin) and northern Chad, in the latest Ordovician-earliest Silurian intervals referred to the base of Tanezzuft Formation.
Among the spiny acanthomorphic acritarchs distinctive subrectangular to subpolygonal forms with unequal distribution of the processes on the vesicle needs to be mentionned. They are attributed to Dorsennidium (Microhystridium?) polorum nov. comb., described in the shallow water Power Glen Formation of the Medina Group, dated as early Rhuddanian in the New York State, USA (Miller \& Eames 1982).

Classically the post-glacial uppermost Ordovician assemblages elsewhere, in more open marine sediments in northern Gondwana or Bohemia are marked by the first appearance of new distinct morphotypes of Silurian affinity such as species of the genera Cymbosphaeridium, Oppilatala, Tylotopalla or Visbysphaera (Dufka \& Fatka 1993, Vecoli \& Le Hérissé 2004, Vecoli 2008, Delabroye \& Vecoli 2010). The occurrence of the species attributed to Dorsennidium polorum in our assemblage of latest Ordovician-earliest Silurian age, is another example of sporadic appearance of species that continue in the early Silurian.

\section{Systematic palaeontology}

\section{Chitinozoa \\ (F. Paris)}

Order Prosomatifera Eisenack, 1972

Family Conochitinidae Eisenack, 1931, emend. Paris, 1981

Subfamily Conochitininae Paris, 1981

\section{Genus Euconochitina Taugourdeau, 1966, emend. Paris et al., 1999}

Type species. - Conochitina conulus Eisenack, 1955.

Figure 8. Acritarchs from the Upper Ordovician-Early Silurian of northern Chad and southeastern Libya. The specimens are housed in the University of Liège (Belgique) under the repository numbers, 60900, 60947, 60949.2, 60949.3, 60950, 60950.1, 60950.3, 60979.3, and in the University of Brest (France) under the repository numbers LPB 13067 to 13070 and 13195 to 13199 . The England-Finder coordinates are in brackets. - A - Villosacapsula setosapellicula (Loeblich, 1970) Loeblich \& Tappan, 1976, Moussegouda core drill, core 9, 220-221 m (A), slide 60950.1 (026.4) • B - Veryhachium mareki Vavrdová, 1989, Moussegouda core drill, core 9, 220-221 m (A), slide 60950.1 (P49.1). C - Neoveryhachium carminae (Cramer, 1964) Cramer, 1970, Moussegouda core drill, core 9, 220-221 m (A), slide 60950.1 (N34.2). • D, E - Saharidia munfarida Vavrdová, 1982; D - Moussegouda core drill, core 9, 220-221 m (A), slide 60950.1 (W39); E - Moussegouda core drill, core 9, 220-221 m (A), slide 60950.1 (E26). • F - Dorsennidium europaeum wenlockianum (Downie, 1959 ex Wall \& Downie, 1963) Sarjeant \& Stancliffe, 1994, emend. Mullins, 2001, Moussegouda core drill, core 8, 205-206 m (A), slide 60979.3 (N49). • G - Multiplicisphaeridium raspa (Cramer) Eisenack et al., 1973, Moussegouda core drill, core 8, 205-206 m, slide 60949.2 (E35.4). • H - Veryhachium subglobosum Jardiné, Combaz, Magloire, Peniguel \& Vachey, 1974, Moussegouda core drill, core 9, 220-221 m (A), slide 60950.3 (C25). • I, J, M - Dorsennidium polorum Miller \& Eames, 1982 nov. comb.; I - KW2 core drill, 36 m, 13194 (F22.2), J - Moussegouda core drill, core 7, 180-186 m, slide 13195 (T24), M - Moussegouda core drill, core 8, 200 m, slide LPB 13196 (C30.2). • K - Tunisphaeridium cf. eisenackii Loeblich \& Tappan, 1978, Moussegouda core drill, core 8, 205-206 m, slide 60949.3 (D39). • L - Multiplicisphaeridium irregulare Staplin, Jansonius \& Pocock, 1965, Moussegouda core drill, core 9, 220-221 m (A), slide 60950 (025). • N - Eupoikilofusa platynetrella Loeblich \& Tappan, 1978, Moussegouda core drill, core 9, $220-221$ m (A), slide 60950 (K46.3). - O - Dactylofusa striatogranulata Combaz, Magloire, Peniguel \& Vachey, 1974, Moussegouda core drill, core 5, 150-156 m, slide 13198 (M19). - P - Eupoikilofusa striatifera (Cramer, 1964) Cramer, 1970, Moussegouda core drill, core 8, 200 m, slide 13197 (W33). Q Q - Eupoikilofusa cf. Eupoikilofusa striata (Staplin, Jansonius \& Pocock, 1965) Eisenack, Cramer \& Diez, 1976, a specimen with striae at the poles and blunt poles, Moussegouda core drill, core 5, 150-156 m, slide 13198 (E27). • R - Eupoikilofusa striata (Staplin, Jansonius \& Pocock, 1965) Eisenack, Cramer \& Diez, 1976, Moussegouda core drill, core 7, 180-186 m, slide 13195 (K31). 
Alain Le Hérissé et al. • Late Ordovician-earliest Silurian palynomorphs from northern Chad

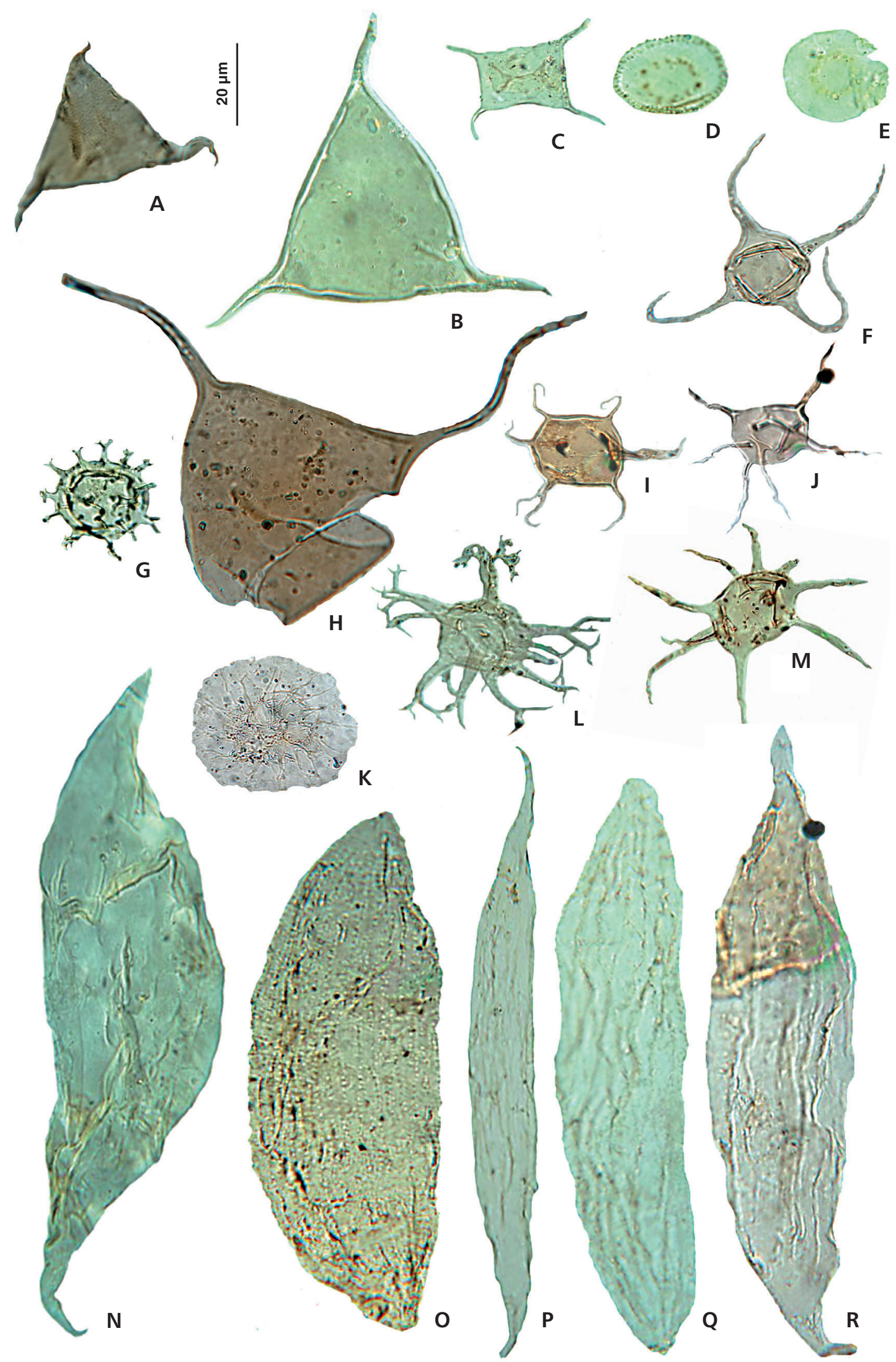




\section{Euconochitina moussegoudaensis sp. nov.} Figures 6A, B, I, J, 7D

1991 Conochitina chydaea Jenkins. - Grignani et al., pl. 1, figs $2-10$.

2013 Euconochitina moussegoudaensis Paris in Thusu et al., pl. VI, figs 4a, b, 8a, b; pl. 7, fig. 5; pl. VIII, figs $3 \mathrm{a}, \mathrm{b}, 4,5 \mathrm{a}, \mathrm{b}$; pl. X, figs 1, 5-10, 12, 14-16, 18; pl. XI, figs 16, 18-20.

Holotype. - Fig. 6J, IGR 58094 (O40).

Paratypes. - Fig. 6A, IGR 58092 (Q39); 6B IGR 58092 (R39); 6I, IGR 58093 (U40/4).

Etymology. - Species name referring to the locality Moussegouda, northern Chad.

Material. - Several tens of specimens in the Moussegouda core hole (northern Chad) and several hundreds of additional specimens from JA-2 core hole, Jebel Asba, Kufra Basin, SE Libya (see Thusu et al. 2013 in press).

Type locality. - Moussegouda shallow core hole, northern Chad.

Type horizon. - Core 3, at depth 123-124 m, basal Tanezzuft Formation referred to the latest Hirnantian-basal Rhuddanian?.

Diagnosis. - Conochitinidae with an elongate conical vesicle, a glabrous wall surface, a straight aperture, and a rounded margin; a slight constriction of the flanks occurs in the lower third of the chamber; neck short.

Description. - This rather small conical chitinozoan (vesicle length ranging from $\mathrm{ca} 105$ to 190 micrometers; see Fig. 5) has sigmoid flanks due to the occurrence of a discrete constriction above the margin, roughly in the lower third of the chamber, i.e. about $1 / 5$ of the total length of the vesicle. The flexure and the shoulder are inconspicuous. The neck is cylindrical or flares gently towards a straight aperture. It is fairly short and represents usually $1 / 4$ to $1 / 3$ of the vesicle length. A well-developped prosome usually provided with a rica (up to 40 micrometers) is frequently present at the base of the neck (Fig. 6B; see also pl. X, figs 5, 6, 8-10 in Thusu et al. 2013 in press). The chamber wall is glabrous, i.e. it bears no spines or cones, but shows a microgranular surface at high magnification (granule diameter less than 1 micrometer; see Fig. 6A2, J2). These granules are better developed on the rounded margin. The chamber bottom is flat to slightly convex (the convexity may be accentuated during the compression of the vesicle). The apex of the chamber is devoid of any conspicuous mucron.

Measurements. - (See Fig. 5.) Because the species is much more abundant in JA-2 core hole, Kufra Basin, the biometric evaluation is made on a population ( 50 specimens) randomly measured in a preparation from $48.18 \mathrm{~m}$ depth in JA-2 core hole. Correction coefficients of 0.8 and 0.7 are respectively used for the chamber width $(\mathrm{Dp})$ and the collarette diameter (Dcoll.) as the compression of the vesicle is moderate, both in the Moussegouda and JA-2 material.

\begin{tabular}{lrrr}
\hline & $\mathrm{L}(\mu \mathrm{m})$ & $\mathrm{Dp}(\mu \mathrm{m})$ & Dcoll. $(\mu \mathrm{m})$ \\
\hline Holotype & 157 & 71 & 45 \\
Paratypes & $151-169$ & $71-85$ & $47-55$ \\
Mean & & 69 & 44 \\
(JA-2, 50 specimens) & 153 & $* 55$ & $* * 31$ \\
Smallest value & & 57 & 34 \\
(JA-2, 50 specimens) & 114 & $* 46$ & $* * 24$ \\
Largest value & & 79 & 54 \\
(JA-2, 50 specimens) & 195 & $* * 63$ & $* * 38$ \\
\hline
\end{tabular}

coefficient of correction $=0.8 ; * *$ coefficient of correction $=0.7$

Discussion. - Because of its glabrous vesicle, Euconochitina moussegoudaensis Paris sp. nov., like most of the Euconochitina species, lacks clear and fully discriminating features. The vesicle size (L ranging from 115 to 195 micrometers),

Figure 9. Prasinophycean phycomata, chlorophycean microalgal remains and problematica from the Upper Ordovician of northern Chad and southeastern Libya. - A, B, F - Tasmanites tzadiaensis nov. sp.; A - holotype, Moussegouda core hole, core 8, $201-202$ m, slide 60948 (K46.4), B - paratype, Moussegouda core hole, core 8, 104-105 m, slide 60900 (M35.3), F - Moussegouda core drill, core 8, 201-202 m, slide 1 LPB 13199 (F33.2). - C-Retisphaeridium? fragile Miller \& Eames, 1982, Moussegouda core hole, core 8, $200 \mathrm{~m}$, LPB 13067 (G47). The form is flattened and bears no equatorial reticulum, as for the type material. • D - Dictyotidium sp., Moussegouda core hole, core 8, 201-202 m, LPB 13199 (Q27). E - Clypeolus tortugaides Miller, Playford \& Le Hérissé, 1997, Moussegouda core hole, core 8, 200 m, slide 60947 (C35.1). • G - Tasmanites sp., Moussegouda core drill, core 8, 205-206 m, slide snpa LPB 13068(Q31). Large form with rugulate to corrugate ornamentation. • H - Tasmanites sp., Moussegouda core hole, core 5, 150-156 m, LPB 13198 (P27). Large form with punctate ornamentation. • I, J, K - possible metazoan remains; I - Moussegouda core hole, core 5, 150-156 m, LPB13198 (J41.2), J - Moussegouda core hole, core 5, 150-156 m, LPB 13198 (S38), K - Moussegouda core hole, core 7, 180-186 m, LPB 13195 (H18.3). • L - Moyeria cabottii (Cramer) Miller \& Eames, 1982, Moussegouda core hole, core 5, 150-156 m, LPB 13198 (E23.2). M - Tasmanites sp. Moussegouda core hole, core 3, 120-126 m, LPB 13069 (C26.3). A small specimen of Tasmanites, with a diameter of 40 um, but very thick vesicle wall of $5.5 \mu \mathrm{m}$ width. $\bullet \mathrm{N}, \mathrm{O}-$ Gleocapsomorpha prisca Zalessky, 1917; N - large colony of connecting cells, enclosed in a lamellated sheath, dimensions $90 \times 135 \mu \mathrm{m}$, Moussegouda core drill, core 8, 220-221 m, LPB 13199 (K45.4), O - colony, $83 \mu \mathrm{m}$ in diameter, Moussegouda core drill, core 4, 135-141 m, LPB 13070 (L24.2) • P, Q - eurypterids fragments; P - eurypterid cuticle spine, Moussegouda core drill, core 8, 200 m, LPB 13199 (R38.3), Q - nail-shaped thickenings from eurypterid cuticle fragment, Moussegouda core drill, core 3, 120-126 m, LPB 13070 (S28). 

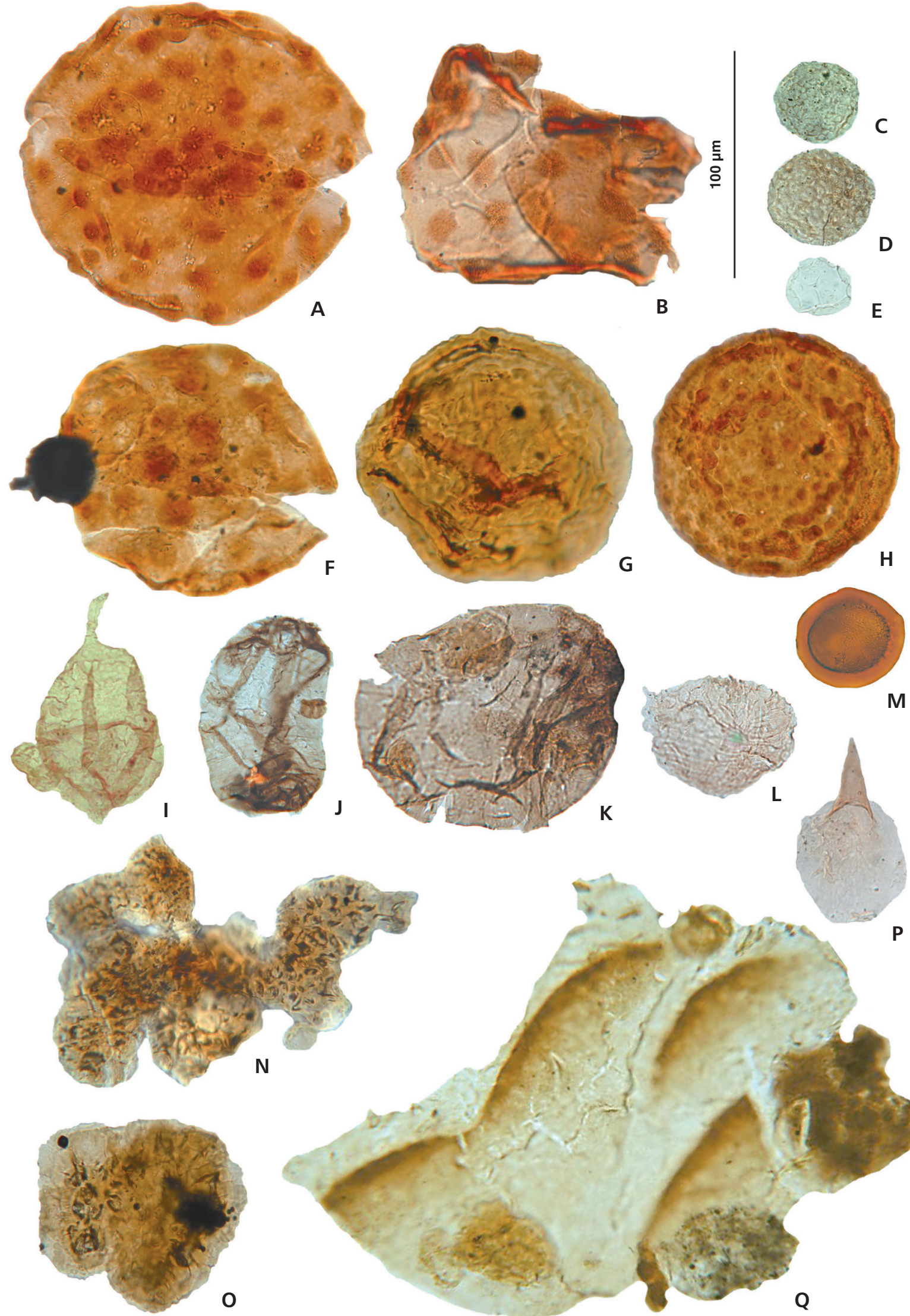

M
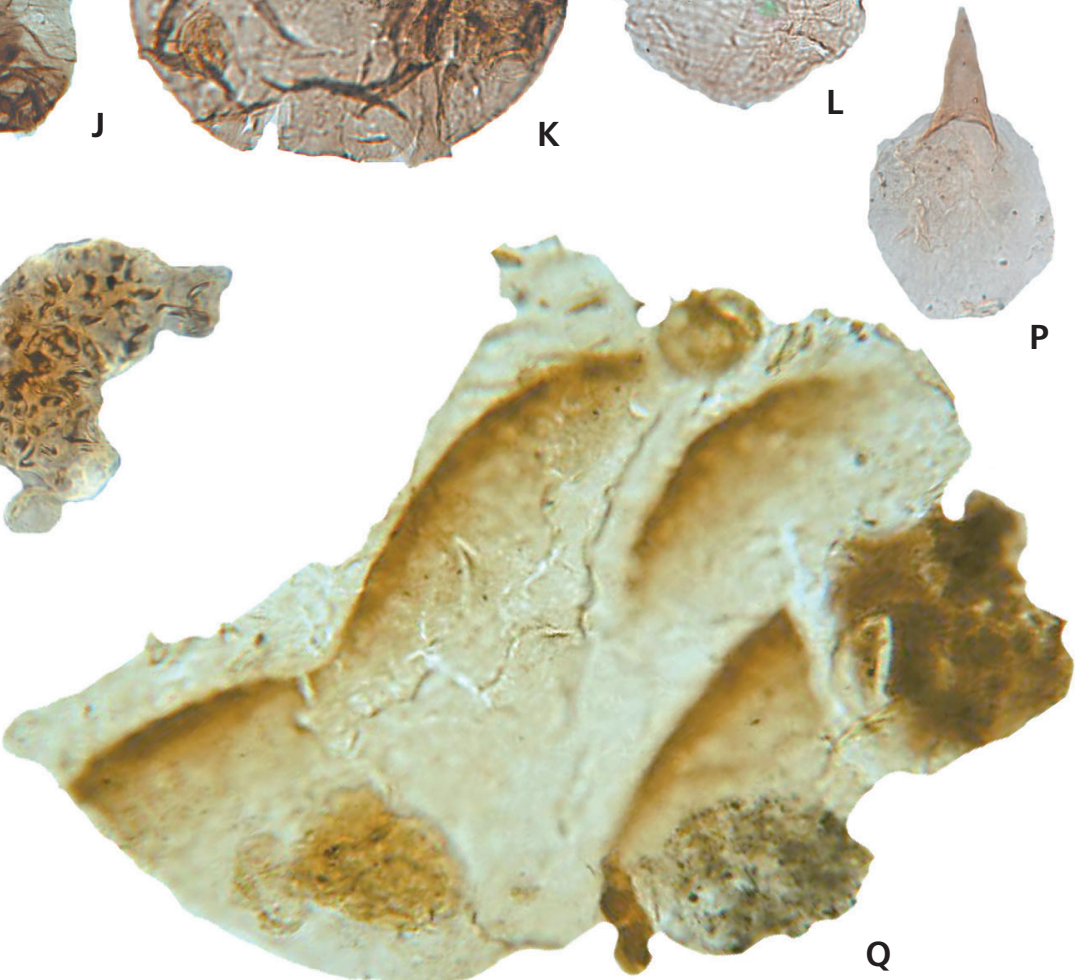
and the overall silhouette with the gently tapering flanks (Dp/Dcoll. close to 1.5) and the weak constriction of the chamber above the margin are the main diagnostic morphological elements. This silhouette separates the new species from other early Silurian Conochitininae, such as C. edjelensis Taugourdeau, 1963, C. elongata Taugourdeau, 1963 or E. vitrea (Taugourdeau 1962).

Stratigraphical and geographical distribution. - Euconochitina moussegoudaensis dominates the rather poor chitinozoan assemblage recovered from a siltstone dominated sequence tentatively referred to the lower part of the Tanezzuft Formation in core 1 to core 8 from the Moussegouda core hole (northern Chad). These strata are regarded as latest Hirnantian or earliest Rhuddanian in age. No independent stratigraphical control, by mean of graptolite data, is available in this core hole.

The species is extremely abundant in the JA-2 core hole and in the neighbouring Remsa well (Kufra Basin SE Libya) from strata tentatively assigned to the latest Hirnantian or earliest Rhuddanian (Thusu et al. 2013 in press). If one accepts the synonymy proposed herein, E. moussegoudaensis was also recorded by Grignani et al. (1991) in core 4 (36-37 m depth) from well KW-2. The corresponding strata yielded us specimens of E. moussegoudaensis associated with $S$. verniersi (see above). The graptolite Normalograptus medius reported by Grignani et al. (1991) in cores 2 (18-19 m) and 3 (30-31 m) from this well does not provide a definite age assignment for this material as the species ranges through the Ordovician-Silurian boundary (see Loydell 2012).

\section{Prasinophyte phycomata (A. le Hérissé)}

Division Chlorophyta Pascher, 1914

Class Prasinophyceae Christensen, 1962

Order Pterospermatales Schiller, 1925

Family Tasmanitaceae Sommer, 1956

\section{Genus Tasmanites Newton, 1875}

Type species. - Tasmanites punctatus Newton, 1875, by original designation.

\section{Tasmanites tzadiaensis sp. nov.} Figure 9A, B, F

Holotype. - Fig. 9A, core 8, 201-202 m, slide 60948 Liège (K46/4).

Paratypes. - Fig. 9B, core 8, 104-105 m, slide 60900 Liège (M35/3); Fig. 9F, core 8, 201-202 m, LPB 131999 (F33/2).

Etymology. - From the Latin name of Chad.

Material. - 20 specimens from core 8 (201-202 m) to core 2 (104-105 m).

Type locality. - Moussegouda shallow core drill, northern Chad.

Type horizon. - Core 8, at depth 201-202 m, basal Tanezzuft Formation referred to the late Hirnantian to early Rhuddanian.

Diagnosis. - A species of Tasmanites, with spherical vesicle, thick-walled, and characteristic discoid ornaments or low verrucae, regularly distributed on the surface, finely pitted by small pores continuing by narrow canals. The opening has not been observed.

Dimensions. - 100 to more than $145 \mu \mathrm{m}$ in diameter; wall 2-3 $\mu \mathrm{m}$ in thickness; discoid ornaments 6.5 to $11 \mu \mathrm{m}$ in diameter.

Discussion. - Diagnostic morphological features such as radial pores confirm the attribution of the species to the genus

Figure 10. Cryptospores from the Upper Ordovician of northern Chad and southeastern Libya. The specimens are housed in the University of Liège (Belgique) under the repository numbers, 60901, 60947, 60948, 60950, 60979. The England-Finder coordinates are in brackets. All specimens $\times 1000$. -A - Rugosphaera cerebra Miller \& Eames, 1982, Moussegouda core hole, core 9, 220-221A, slide 60950 (H30/4). B, C - Dyadospora murusattenuata Strother \& Traverse, 1979; B - Moussegouda core hole, core 9, 220-221A m, slide 60950 (Q34.3), C - Moussegouda core drill, core 8, 201-202 m, slide 60948 (L31/2). • D, E - Imperfectotriletes vavrdovae Steemans et al., 2000; D - Moussegouda core hole, core 8, $200 \mathrm{~m}$, slide 60947 (H33), E - Moussegouda core drill, core 8, 201-202 m, slide 60948 (Q28/2). • F - Pseudodyadospora sp., Moussegouda core hole, core 8, 201-202 m, slide 60948 (G25). • G - Rimosotetras problematica Burgess, 1991, Moussegouda core hole, core 9, 220-221 m, slide 60950 (C34/1). • H - Segestrespora laevigata Burgess, 1991, Moussegouda core hole, core 8, 201-202 m, slide 60948 (M38). • I - Segestrespora membranifera (Johnson, 1985) Burgess, 1991, Moussegouda core hole, core 8, 205-206 m, slide 60979 (L37). J - Segestrespora rugosa (Johnson, 1985) Burgess, 1991, Moussegouda core drill, core 9, 220-221A m, slide 60950 (C33/1). • K - Tetrahedraletes grayii Strother, 1991, Moussegouda core hole, core 9, 220-221A m, slide 60950 (Q34/3). • L - Tetrahedraletes medinensis Strother \& Traverse, 1979, Moussegouda core hole, core 9, 220-221A m, slide 60950 (J30/4). - M - Velatitetras laevigata Burgess, 1991, Moussegouda core hole, core 8, 201-202 m, slide 60948 (H37). • N - Velatitetras retimembrana (Miller \& Eames, 1982) Wellman \& Richardson, 1996, Moussegouda core hole, core 3, 123-124 m, slide 60901 (H36). • O - Velatitetras rugosa (Strother \& Traverse, 1979) Steemans et al., 2000, Moussegouda core hole, core 9, 220-221A m, slide 60950 (Q30). 
Alain Le Hérissé et al. • Late Ordovician-earliest Silurian palynomorphs from northern Chad
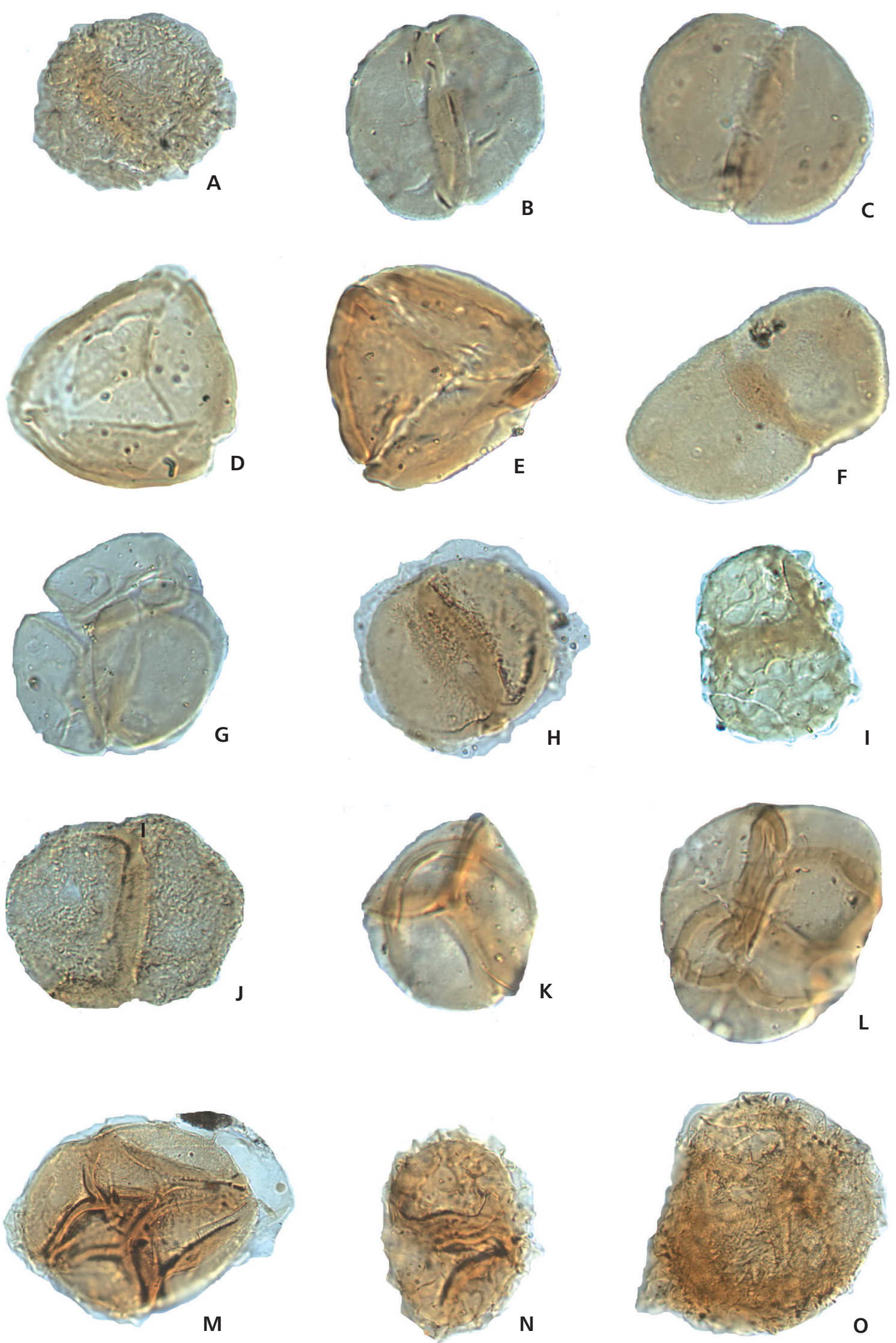
Tasmanites. Tasmanites tzadiaensis sp. nov. differs from the other species of the genus in having a very particular surface ornamentation. It recalls Tapajonites roxoi Sommer \& Van Boekel, 1963, showing some little dark spots on the surface, but the latter are irregularly distributed and without any pores. A few additional specimens are characterized by corrugate ornamentation, and are identified as Tasmanites sp. A, and some with verrucate ornamentation, illustrated as Tasmanites sp. B. They are rare and therefore are kept in open nomenclature. Specimens of various size attributed to Leiosphaeridia (very abundant) are comparatively thin walled and have no pores or canals.

Stratigraphical and geographical distribution. - Tasmanites tzadiaensis is recorded in an interval referred to the basal Tanezzuft Formation in northern Chad, in Moussegouda core hole between 201-202 m and 104-105 m (present study). The species is also mentioned in subsurface deposits of the Jebel Asba area, Kufra Basin, southeast Libya in an interval also referred to the latest Ordovician-earliest Silurian Tanezzuft Formation (Thusu et al. 2013 in press).

\section{Conclusions}

This paper has provided biostratigraphical information and interpretation for the sedimentary sequence within the Late Ordovician to earliest Silurian (?) succession in the subsurface of the northern Chad and in southeastern Libya that can be summarised as follows. The microfossils from the glacio-marine deposits in the deeper part (C10 and C9) of the core section of the Moussegouda core hole, clearly indicate a Hirnantian age for these deposits. Evidence of acritarch and possibly chitinozoan reworking are consistent with this age assignment, as reworking is a common feature of Late Ordovician glacial to end-glacial deposits in northern Gondwana regions. In the Moussegouda core hole, the Hirnantian diamictites are overlain by a sequence of siltstones and sandstones with carbonaceous horizons, referred to the Tanezzuft Formation. Cores 1 to 4 from the KW-2 shallow well in southeastern Libya are also referred to this formation. In both areas these strata correspond to post-glacial deposits generated by the dramatic sea-level rise resulting from the final melting of the main part of the Gondwanan inlandsis. These deposits seem concentrated in short-lived shallow marine depressions that developed prior to the post-glacial rebound in areas previously overlain by a thick ice cover. This sedimentation starved rapidly due to these isostatic readjustments and did not shift to hemipelagic graptolite-bearing shales as commonly observed during the Rhuddanian and even later, in many localities along the north Gondwanan margin. The admixture of land-derived, freshwater and marine palynomorphs in the Moussegouda material, and evidence of low salinity indicate a strong continental influx. These features suggest the existence of nearshore restricted environments consistent with the filling up of large but shallow depressions (several tens of meters to one or two hundred meters depth) with moderate oceanic communication. The duration of such sedimentological processes was in the range of a few thousand years if one refers to the timing of the Holocene transgression and to the contemporaneous post-glacial rebound in north European areas, where a thick ice cover occurred during Quaternary times.

\section{Acknowledgements}

The authors are greatly indebted to the late Dominique Massa, who provided the core material and numerous valuable unpublished reports and data on the Moussegouda core hole. They sincerely thank also B. Thusu and G. Meinhold for access to their palynological data from the JA-2 core hole, Jebel Asba, SE Libya. The authors are greatly indebted to A. Butcher (University of Portsmouth, School of Earth and Environmental Sciences, U.K.), and C.H. Wellman (University of Sheffield, Department of Animal and Plant Sciences, U.K.), for their exhaustive reading, comments and corrections of the manuscript.

\section{References}

AchaB, A. 1978. Chitinozoaires de l'Ordovicien supérieur - formations de Vauréal et de Ellis Bay - de l'Ile d'Anticosti, Québec, Canada. Palinologia, Numero extraordinario, 1-20.

Аснав, А. 1981. Biostratigraphie par les chitinozoaires de l'Ordovicien supérieur-Silurien inférieur de l'Ile de Anticosti. Résultats préliminaries, 143-157. In LesPerance, P.J. (ed.) Field meeting Stratigraphy and Paleontology, AnticostiGaspé, Québec, vol. II: Stratigraphy and Paleontology. IUGS subcommission on Silurian Stratigraphy Ordovician-Silurian Boundary Working Group.

Al-Ameri, T.K. 1983. Acid-resistant microfossils used in the determination of Paleozoic palaeoenvironments in Libya. $\mathrm{Pa}$ laeogeography, Palaeoclimatology, Palaeoecology 44, 103-116. DOI 10.1016/0031-0182(83)90007-X

AL-HajRi, S. \& Owens, B. 2000. Sub-surface Palynostratigraphy of the Palaeozoic of Saudi Arabia, 10-17. In AL-HaJRI, S. \& Owens, B. (eds) Palaeozoic palynostratigraphy of Saudi Arabia. GeoArabia, Special Publication 1. Elsevier Science.

Armstrong, H.A., Turner, B.R., Makhlouf, I.M., Weedon, G.P., Williams, M., Al-Smadi, A. \& Abu Salah, A. 2005. Origin, sequence stratigraphy and depositional environment of an Upper Ordovician (Hirnantian) degalacial black shale, Jordan. Palaeogeography, Palaeoclimatology, Palaeoecology 220(3-4), 273-289. DOI 10.1016/j.palaeo.2005.01.007

Bellini, E. \& MASSA, D. 1980. A stratigraphic contribution to the Paleozoic of the southern basins of Libya, 3-56. In SALEM, M.J. \& BusrewiL, M.T. (eds) The Geology of Libya I. Academic Press, London.

Blokker, P., Van Bergen, P., Pancost, R., Collinson, M.E., 
De Leeuw, J.W. \& Sinninghe Damste, J.S. 2001. The chemical structure of Gloeocapsomorpha prisca microfossils: implication for their origin. Geochemica and Cosmochimica Acta 65(6), 885-900. DOI 10.1016/S0016-7037(00)00582-2

Bourahrouh, A. 2002. Chitinozoaires et palynomorphs de l'Ordovicien Supérieur nord gondwanien: impact de la glaciation ashgillienne. $300 \mathrm{pp}$. PhD thesis, University of Rennes I (unpublished).

Bourahrouh, A., Paris, F. \& Elaouad-Debbaj, Z. 2004. Biostratigraphy, biodiversity and palaeoenvironments of the chitinozoans and associated palynomorphs from the Upper Ordovician of the Central Anti-Atlas, Morocco. Review of Palaeobotany and Palynology 130, 17-40. DOI 10.1016/j.revpalbo.2004.01.002

BURGESS, N.D. 1991. Silurian cryptospores and miospores from the type Llandovery area, south-west Wales. Palaeontology $34,575-599$.

Butcher, A. 2009. Early Llandovery chitinozoans from Jordan. Palaeontology 52(3), 593-629.

DOI 10.1111/j.1475-4983.2009.00862.x

Christensen, T. 1962. Botanik, Bind 2. Systematic botanik. No. 2, Alger. 178 pp. Munksgaard, København.

Colbath, G.K. \& Grenfell, H.R. 1995. Review of biological affinities of Palaeozoic acid-resistant organic-walled eukaryotic algal microfossils (including "acritarchs"). Review of Palaeobotany and Palynology 86, 287-314. DOI 10.1016/0034-6667(94)00148-D

DA CostA, N.M. 1971. Quitinozoarios silurianos do Igarape da Raiha, Estado do Para. Departamento Nacional da Produção Mineral. Divisão de Geologia e Mineralogia Boletim 221, $1-101$.

Delabroye, A. \& Vecoli, M. 2010. The end-Ordovician glaciation and the Hirnantian Stage: A global review and questions about Late Ordovician event stratigraphy. Earth Science Reviews 98, 269-282. DOI 10.1016/j.earscirev.2009.10.010

Derenne, S., Largeau, C., Casadevall, E., Sinninghe Damste, J.S., Tegelaar, E.W., Damste, J.S. \& De Leeuw, J.W. 1990. Characterization of Estonian Kukersite by spectroscopy and pyrolisis: evidence for abundant alkyl phenolic moieties in an Ordovician, marine, type II/I kerogen. Organic Geochemistry 16, 873-888. DOI 10.1016/0146-6380(90)90124-I

Derenne, S., Metzger, P., Largeau, C., Van Bergen, P.F., Gatellier, J.P., Sinninghe Damste, J.S., De Leeuw, J.W. \& BERKALOFF, C. 1992. Similar morphological and chemical variations of Gleocapsomorpha prisca in Ordovician sediments and cultured Botryococus braunii as a response to change in salinity. Organic Geochemistry 19, 299-313. DOI 10.1016/0146-6380(92)90001-E

DoRNING, K.J. 1981. Silurian acritarch distribution in the Ludlovian shelf sea of South Wales and the Welsh Borderland, 31-36. In Neale, J.W. \& Brasier, M.D. (eds) Microfossils from recent and fossil shelf seas. Ellis Horwood, Chichester.

DoRNING, K.J. \& HARDING, J.L. 1998. Environmental distribution of the Ordovician-Recent terrestrial to freshwater acritarchs and algae, including Concentricystes, Moyeria and Pediastrum. CIMP Symposium and Workhops, Pisa, September 11-15, Abstracts, 37.

DuFFIELD, S.L. 1985. Land-derived microfossils from the Jupiter Formation (Upper Llandoverian), Anticosti Island, Quebec. Journal of Paleontology 59, 1005-1010.

DuFKa, P. \& FATKA, O. 1993. Chitinozoans and acritarchs of the Ordovician-Silurian boundary from the Prague Basin (Bar- randian area: Czechoslovakia), 7-16. In Molyneux, S.G. \& Dorning, K.G. (eds) Contribution to Acritarch and Chitinozoa Research. Special Papers in Palaeontology 48.

EISENACK, A. 1931. Neue Mikrofossilien des Baltischen Silurs I. Palaeontologische Zeitschrift 13, 74-118.

Eisenack, A. 1955. Neue Chitinozoen aus dem Silur des Baltikum und dem Devon der Eifel. Senckenbergiana lethaea 36, 311-319.

EisenACK, A. 1972. Beiträge zur Chitinozoen-Forschung. Paleontographica, Abteilung A 140, 117-130.

Finney, S.C., Berry, W.B.N., CoOper, J.D., RipPerdan, R.L., Sweet, W.C., Jacobson, S.R., Soufinae, A., Achab, A. \& Noble, P.J. 1999. Late Ordovician mass extinction: a new perspective from stratigraphic sections in central Nevada. Geology 27, 215-218.

DOI 10.1130/0091-7613(1999)027<0215:LOMEAN>2.3.CO;2

Fello, N., LÜNING, S., ŠTORCH, P. \& REDFERN, J. 2006. Identification of early Llandovery (Silurian) anoxic palaeodepressions at the western margin of the Murzuq Basin (southwest Libya), based on gamma-ray spectrometry in surface exposures. GeoArabia 11, 101-108.

Foster, C.B., WicAnder, R. \& Reed, J.D. 1989. Gleocapsomorpha prisca Zalessky, 1917: a new study. Part I: taxonomy, geochemistry and paleoecology. Geobios 22(6), 735-759. DOI 10.1016/S0016-6995(89)80070-1

Foster, C.B., Wicander, R. \& Reed, J.D. 1990. Gleocapsomorpha prisca Zalessky, 1917: a new study. Part II: origin of Kukersite, a new interpretation. Geobios 23(2), 133-140. DOI 10.1016/S0016-6995(06)80045-8

Fowler, M.G., Stasiuk, L.D., Heam, M. \& Obermajer, M. 2004. Evidence for Gloecapsomorpha prisca in Late Devonian source rocks from Southern Alberta, Canada. Organic Geochemistry 36(4), 426-441.

GHIENNE, J.F. 2003. Late Ordovician sedimentary environments, glacial cycles, and post-glacial transgression in the Taoudeni Basin, West Africa. Palaeogeography, Palaeoclimatology, Palaeoecology 189, 117-145. DOI 10.1016/S0031-0182(02)00635-1

Gray, J. \& Boucot, A.J. 1989. Is Moyeria a euglenoid? Lethaia 22, 447-456. DOI 10.1111/j.1502-3931.1989.tb01449.x

Gray, J., Boucot, A.J., Grahn, Y. \& Himes, G. 1992. A new record of early Silurian land plant spores from the Parana Basin, Paraguay (Malvinokaffric Realm). Geological Magazine 129, 741-752. DOI 10.1017/S0016756800008463

Grignani, D., Lanzoni, E. \& Elatrash, H. 1991. Palaeozoic and Mesozoic Subsurface Palynostratigraphy in Al Kufrah Basin, Libya, 1159-1227. In SALEM, M.J. (ed.) Geology of Libya IV. Elsevier, Amsterdam.

GuY-Ohlson, D. 1996. Prasinophycean algae, 181-189. In JANsonius, J. \& McGregor, D.C. (eds) Palynology: Principles and applications. American Association of Stratigraphic Palynologists Foundation, Dallas 1.

Hirst, J.P.P., Benbakir, A., Payne, D.F. \& Westlake, I.R. 2002. Tunnel valleys and density flow processes in the Upper Ordovician glacial succession, Illizi Basin, Algeria: influence on reservoir quality. Journal of Petroleum Geology 25, 297-324. DOI 10.1111/j.1747-5457.2002.tb00011.x

JACOBSON, S.R. 1979. Acritarchs as paleoenvironmental indicators in middle and upper Ordovician rocks from Kentucky, Ohio and New York. Journal of Paleontology 53, 1197-1212.

JANSSON, I.M., McLoughlin, S. \& VAJDA, V. 2008. Early Jurassic annelid cocoons from eastern Australia. Alcheringa 32, 285-296. DOI 10.1080/03115510802096226 
Jardiné, S., Combaz, A., Magloire, L., Peniguel, G. \& Vachey, G. 1974. Distribution stratigraphique des acritarches dans le Paléozoïque du Sahara Algérien. Review of Palaeobotany and Palynology 18, 99-129.

DOI 10.1016/0034-6667(74)90012-8

Johnson, N.G. 1985. Early Silurian palynomorphs from the Tuscarora Formation in central Pennsylvania and their paleobotanical and geological signification. Review of Palaeobotany and Palynology 45, 307-360. DOI 10.1016/0034-6667(85)90006-5

KLITSCH, E. 1981. Lower Paleozoic rocks of Libya, Egypt and Sudan, 131-164. In Holland, C.H. (ed.) Lower Paleozoic of the Midle East, Eastern and Southern Africa and Antartica. John Wiley, New York.

KLITSCH, E. \& Wicisk, P. 1987. Geology of sedimentary basins of northern Sudan and bordering areas. Berliner geowissenschaftliche Abhandlugen A 75, 97-136.

Lakova, I., Gocev, P.M. \& Yanev, S. 1992. Palynostratigraphy and geological setting of the Lower Paleozoic allochthon of the Dervent Heights, SE Bulgaria. Geological Balcanica 22, $71-88$.

Laranjeira, N.P.F., Melo, J.H.G. \& Pereira, E. 1997. New palynological dating of the Vila Maria Formation (Silurian, Paraná Basin) in southwestern Goiás State, west-central Brazil. III CRONOPAR, Barra do Garças - Brazil, UERJ/Pref. Barra do Garças (MT), October 5-11 1997, Abstract Volume, 4-5.

LEGRAND, P. 1981. Essai sur la paléogéographie du Silurien au Sahara algérien. Compagnie Française des Pétroles, Notes et Mémoires 16, 9-24.

Legrand, P. 2009. Faunal specificity, endemism and paleobiogeography: the post-glacial (Hirnantian-early Rhuddanian) graptolite fauna of the North African border of Gondwana: a case of study. Bulletin de la Société Géologique de France 180, 353-367. DOI 10.2113/gssgfbull.180.4.353

Le Heron, D.P., Craig, J. \& Etienne, J.L. 2009. Ancient glaciations and hydrocarbon accumulations in North Africa and the Middle East. Earth Science Reviews 93, 47-76. DOI 10.1016/j.earscirev.2009.02.001

Le Heron, D.P., Craig, J., Sutcliffe, O.E. \& Whittington, R. 2006. Late Ordovician glaciogenic reservoir heterogeneity: an example from the Murzuq Basin, SW Libya. Marine and Petroleum Geology 23, 655-677.

DOI 10.1016/j.marpetgeo.2006.05.006

Le Hérissé, A., Bourahrouh, A., Vecoli, M. \& Paris, F. 2003. Palynological tracers of sea-ice cover extent during the latest Ordovician on the North African margin. AAPG Hedberg Conference. Paleozoic and Triassic Petroleum Systems in North Africa, February 18-20, 2003, Algiers, Algeria, Abstract book, 79 .

Le Hérissé, A., Dorning, K.J., Mullins, G.L. \& Wicander, R. 2009. Global patterns of organic-walled phytoplankton biodiversity during the Late Silurian to earliest Devonian. Palynology 33(1), 25-75.

LoEBLICH, A.R. JR. 1970. Morphology, ultrastructure and distribution of Paleozoic acritarchs. Proceeding North American Paleontological Convention, Chicago 1969, Part G, 705-788.

Loeblich, A.R., JR. \& TAPPAn, H. 1978. Some Middle and Late Ordovician microphytoplankton from Central North America. Journal of Paleontology 52(6), 1233-1287.

Loydell, D. 2007. Graptolites from the Upper Ordovician and Lower Silurian of Jordan. Special Papers in Palaeontology 78, $1-66$.
LoYdeLL, D. 2012. Graptolite biostratigraphy of the E1-NC174 core, Rhuddanian (lower Llandovery, Silurian), Murzuq Basin (Libya). Bulletin of Geosciences 87, 651-660. DOI 10.3140/bull.geosci.1311

LOYdELl, D.K., Butcher, A., FrÝdA, J., LÜNING, S. \& Fowler, M. 2009. Lower Silurian "hot shales" in Jordan: a new depositional model. Journal of Petroleum Geology 32(3), 261-270. DOI 10.1111/j.1747-5457.2009.00447.x

LÜning, S., Craig, J., Fitches, B., Mayouf, J., Busrewil, A., El Dieb, M., Gammudi, A., Loydell, D. \& McIlroy, D. 1999. Re-evaluation of the petroleum potential of the Kufra Basin (SE Libya, NE Cad): does the source rock barrier fall? Marine and Petroleum Geology 16, 693-718. DOI 10.1016/S0264-8172(99)00013-6

Lüning, S. \& Fello, N. 2008. Silurian "Hot Shales" in the Murzuq and Al-Kufrah Basins (S. Libya): improved predictability of source rock distribution based on gamma-ray spectrometry in surface exposures, 3-12. In SALEM, M.J., Oun K.M. \& EsSED, A.S. (eds) The Geology of East Libya, Vol. IV. Gutenberg Press, Malta.

Lüning, S., Shahin, Y.M., Loydell, D., Al-Rabi, H.T., MasRi, A., TARAwneh, B. \& Kolonic, S. 2005. Anatomy of a worldclass source rock: distribution and depositional model of Silurian organic-rich shales in Jordan and implications for hydrocarbon potential. AAPG Bulletin 89, 1397-1427. DOI 10.1306/05250505014

Manum, S.B. 1996. Chapter 13B Clitellate cocoons, 361-364. In Jansonius, J. \& McGregor, D.C. (eds) Palynology: principles and applications. American Association of Stratigraphic Palynologists Foundation, 1.

Manum, S.B., Bose, M.N. \& SAwyer, R.T. 1991. Clitellate cocoons in freshwater depositys since the Triassic. Zoologia Scripta 20, 347-366. DOI 10.1111/j.1463-6409.1991.tb00300.x

Martin, F. 1993. Acritarchs: a review. Biological Review 68, 475-538. DOI 10.1111/j.1469-185X.1993.tb01241.x

MASSA, D. \& JAEGER, H. 1971. Données stratigraphiques sur le Silurien de l'Ouest de la Libye. Mémoires du Bureau de Recherches Géologiques et Minières 73, 313-321.

Melo, J.H.G. 1997. Nova dataçao palinologica da Formação Vila Maria (Siluriano, Bacia do Paraná em sua faixa de afloramentos no SW de Goias. Petrobras (Internal Report), 1-15.

Melo, J.H.G. \& SteEmans, P. 1997. Resultados de investigacoes palinoestratigraficas em amostras de superficie da regiao de Presidente Figueiredo (AM), Bacia do Amazonas. Petrobras (Internal Report), 1-11.

Miller, A. \& EAmES, L. 1982. Palynomorphs from the Silurian Medina Group (Lower Llandovery) of the Niagara Gorge, Lewiston, New York, U.S.A. Palynology 6, 221-254.

Miller, C.G., Sutherland, S. \& Dorning, K.J. 1997. Late Silurian (Ludlow-Pridoli) microfossils and sedimentation in the Welsh Basin near Clun, Shropshire. Geological Journal 32, 69-83. DOI 10.1002/(SICI)1099-1034(199703)32:1<69:: AID-GJ734>3.0.CO;2-Q

Mizusaki, A.M.P, Melo, J.H.G., Vignol-Lelarge, M.L. \& SteEMANS, P. 2002. Vila Maria Formation (Silurian, Parana Basin, Brazil): integrated radiometric and palynological age determinations. Geological Magazine 139(4), 453-463. DOI 10.1017/S0016756802006659

Molyneux, S.G. \& PARIS, F. 1985. Late Ordovician palynomorphs, 11-26. In Thusu, B. \& Owens, B. (eds) Palynostratigraphy of North-East Libya. Journal of Micropaleontology 4. 
Monod, O., Kozlu, H., Ghienne, J.F., Dean, W.T., Günay, Y., Le Hérissé, A., PARIS, F. \& Robardet, M. 2003. Late Ordovician glaciation in southern Turkey. Terra Nova 15, 249-257. DOI 10.1046/j.1365-3121.2003.00495.x

Mullins, G.L., Aldridge, R.J. \& Siveter, D.J. 2004. Microplankton associations, biofacies and palaeoenvironment of the type lower Ludlow Series, Silurian. Review of Palaeobotany and Palynology 130, 163-194.

DOI 10.1016/j.revpalbo.2003.12.006

Newton, E.T. 1875. On Tasmanite and Australian White coal. Geological Magazine 2, 337-342. DOI 10.1017/S001675680016008X

NõlvaK, J. 1999. Ordovician chitinozoan zonation of Baltoscandia. Acta Universitatis Carolinae, Geologica 43, 287-290.

NõlvaK, J. \& Grahn, Y. 1993. Ordovician chitinozoan zones from Baltoscandia. Review of Palaeobotany and Palynology 79, 245-269. DOI 10.1016/0034-6667(93)90025-P

Oulebsir, L. \& PARIS, F. 1995. Biostratigraphie des chitinozoaires de l'Ordovicien du Sahara algérien. Review of Palaeobotany and Palynology 86, 49-68. DOI 10.1016/0034-6667(94)00098-5

Paris, F. 1981. Les chitinozoaires dans le Paléozoïque du SudOuest de l'Europe (cadre géologique - étude systématique biostratigraphie). Mémoire de la Société géologique et minéralogique de Bretagne 26, 1-496.

PARIS, F. 1990. The Ordovician chitinozoan biozones of the northern Gondwana Domain. Review of Palaeobotany and Palynology 66, 181-209.

DOI 10.1016/0034-6667(90)90038-K

Paris, F., Bourahrouh, A. \& Le Hérissé, A. 2000a. The effects of the final stages of the Late Ordovician glaciation on marine palynomorphs (chitinozoans, acritarchs, leiospheres) in Well Nl-2 (NE Algerian Sahara). Review of Palaeobotany and Palynology 113, 84-104. DOI 10.1016/S0034-6667(00)00054-3

Paris, F., Deynoux, M. \& Ghienne, J.-F. 1998. Découverte de chitinozoaires à la limite Ordovicien-Silurien en Mauritanie: implications paléogéographiques. Comptes Rendus de l'Académie des Sciences, Paris II, 326, 499-504.

Paris, F., Grahn, Y., Nestor, V. \& Lakova, I. 1999. A revised chitinozoan classification. Journal of Paleontology 73, 547-568.

Paris, F., Le Hérissé, A., Monod, O., Kozlu, H., Ghienne, J-F., Dean, W.T., Vecoli, M. \& Günay, Y. 2007. Ordovician chitinozoans and acritarchs from southern and southeastern Turkey. Revue de Micropaléontologie 50, 81-107. DOI 10.1016/j.revmic.2006.11.004

Paris, F., Miller, M., Al-Hajri, S. \& Zalasiewicz, J. 2013 b. Early Silurian chitinozoans from the Qusaiba type area, North Central Saudi Arabia. GeoArabia, Special Publication (in press).

Paris, F., Thusu, B., Rasul, S., Meinhold, G., Strogen, D., Howard, J.P., Abutarruma, Y., Elgadryl, M. \& Whitham, A.G. 2012. Palynological and palynofacies analysis of early Silurian shales from borehole CDEG-2a in Dor el Gussa, eastern Murzuq Basin, Libya. Review of Palaeobotany and Palynology 174, 1-28. DOI 10.1016/j.revpalbo.2012.02.002

Paris, F., Verniers, J. \& Al-HaJRI, S. 2000b. Ordovician chitinozoans from central Saudi Arabia, 42-56. In Al-HaJRI, S. \& Owens, B. (eds) Palaeozoic palynostratigraphy of Saudi Arabia. GeoArabia, Special Publication 1. Elsevier Science.
Paris, F., Verniers, J., Miller, M., Al-Hajri, S., Melvin, J. \& Wellman, C.H. 2013a. Late Ordovician-earliest Silurian chitinozoans from the Qusaiba core hole (North Central Saudi Arabia) and relation to the Hirnantian glaciation. GeoArabia, Special Publication (in press).

PASCHER, A. 1929. Ueber einige Endosymiosen von Blaualgen in Einzellern. Jahrburg Wissenschaftlich Botanica 71, 386-462.

Richardson, J.B. 1988. Late Ordovician and Early Silurian cryptospores and miospores from northeast Libya, 89-109. In El-Arnauti, A., Owens, B. \& Thusu, B. (eds) Subsurface palynostratigraphy of northeast Libya. Garyounis University Publications, Benghazi.

Richardson, J.B. 1996. Chapter 18A. Lower to middle Palaeozoic records of terrestrial palynomorphs, 391-407. In JANSONIUS, J. \& McGRegor, D.C. (eds) Palynology: principles and applications. American Association of Stratigraphic Palynologists Foundation 2, Dallas.

Rubinstein, C.V., Gerienne, P., De La Puente, G.S., Astini, R.A. \& SteEmans, P. 2010. Early Middle Ordovician evidence for land plants in Argentina (eastern Gondwana). New Phytologist 188, 365-369. DOI 10.1111/j.1469-8137.2010.03433.x

Rubinstein, C., Muro, V. \& Steemans, P. 2011. Miospores from Ordovician-Silurian Argentinean basins: evolution and relationships with other South American basins. AASP Meeting Abstracts, 34.

Semtner, A.-K. \& Klitzsch, E. 1994. Early Paleozoic paleogeography of the northern Gondwana margin: new evidence for Ordovician-Silurian glaciation. Geologische Rundschau 83, 743-751. DOI 10.1007/BF00251072

Sommer, F.W. 1956. South American Paleozoic sporomorphae without haptotypic structures. Micropaleontology 2, 175-181. DOI $10.2307 / 1484101$

Sommer, F.W. \& Van Boeckel, N.M. 1963. Some new Tasmanaceae from the Devonian of Paraná. Anais da Academia Brasileira de Ciências 38, 53-64.

Soufiane, A. \& Achab, A. 2000a. Chitinozoan zonation of the Late Ordovician and the Early Silurian of the Island of Anticosti, Québec, Canada. Review of Palaeobotany and Palynology 109, 85-111. DOI 10.1016/S0034-6667(99)00044-5

Soufiane, A. \& Achab, A. 2000b. Upper Ordovician and Lower Silurian chitinozoans from central Nevada and Arctic Canada. Review of Palaeobotany and Palynology 113, 165-187. DOI 10.1016/S0034-6667(00)00058-0

Steemans, P. 2000. Miospore Evolution from the Ordovician to the Silurian. Review of Palaeobotany and Palynology 113(1-3), 189-196. DOI 10.1016/S0034-6667(00)00059-2

Steemans, P. 2001. Ordovician cryptospores from the Oostduinkerke borehole, Brabant Massif, Belgium. Geobios 34(1), 3-12. DOI 10.1016/S0016-6995(01)80038-3

Steemans, P., Higgs, K.T. \& Wellman, C.H. 2000. Cryptospores and trilete spores from the Llandovery, Nuayyim-2 Borehole, Saudi Arabia, 92-115. In Al-HaJRI, S. \& Owens, B. (eds) Stratigraphic palynology of the Palaeozoic of Saudi Arabia. GeoArabia, Special Publication 1. Elsevier Science.

Steemans, P., Le Hérissé, A. \& Bozdogan, N. 1996. Ordovician and Silurian cryptospores and miospores from southeastern Turkey. Review of Palaeobotany and Palynology 93(1-4), 35-76. DOI 10.1016/0034-6667(95)00119-0

Steemans, P., Le Hérissé, A., Melvin, J., Miller, M., Paris, F., Verniers, J. \& Wellman, C.H. 2009. Origin and radiation of the earliest vascular land plants. Science $324,353$. DOI 10.1126/science.1169659 
Steemans, P. \& Pereira, E. 2002. Llandovery miospore biostratigraphy and stratigraphic evolution of the Parana Basin, Paraguay - Palaeogeographic implications. Bulletin de la Société Géologique de France 173(5), 407-414. DOI 10.2113/173.5.407

Steemans, P., Petus, E., Breuer, P., Mauller-Mendlowicz, P. \& GerienNe, P. 2012. Palaeozoic innovations in the micro- and megafossil plant record: from the earliest plant spores to the earliest seeds, 437-477. In TALENT, J. (ed.) Global biodiversity, extinction intervals and biogeographic perturbations through time. Springer, Dordrecht, London \& New York.

Steemans, P. \& Wellman, C.H. 2004. Miospores and the emergence of land plants, 361-366. In Webby, B., Paris, F., Droser, M.L. \& Percival, I.G. (eds) The Great Ordovician Biodiversification Event. Columbia University Press, New York.

Stevaux, J. \& Kulbicki, G. 1966. Sur la salinité de la mer silurienne au Sahara. Bulletin du Service de la Carte géologique d'Alsace Lorraine 19, 205-212.

S̆тоRсн, P. \& MASSA, D. 2006. Middle Llandovery (Aeronian) graptolites of the western Murzuq Basin and Al Qarqaf Arc Region, South-West Libya. Palaeontology 49(1), 83-112. DOI 10.1111/j.1475-4983.2005.00530.x

Strother, P.K. 1991. A classification schema for the cryptospores. Palynology 15, 219-236. DOI 10.1080/01916122.1991.9989397

Strother, P.K. \& Traverse, A., 1979. Plant microfossils from the Llandoverian and Wenlockian rocks of Pennsylvania. Palynology 3, 1-21. DOI 10.1080/01916122.1979.9989181

Tappan, E. 1980. The Paleobiology of Plant Protists. 1028 pp. W.H. Freeman, San Fransisco.

Taugourdeau, P. 1962. Association de Chitinozoaires dans quelques sondages de la region d'Edjelé (Sahara). Revue de Micropaléontologie 4, 229-236.

Taugourdeau, P. 1963. Etude de quelques espèces critiques de Chitinozoaires de la region d'Edjelé et complements à la faune locale. Revue de Micropaléontologie 6, 130-144.

Taugourdeau, P. 1966. Les chitinozoaires. Techniques d'études, morphologie et classification. Mémoire de la Société Géologique de France, Nouvelle Série 45, 1-64.

Thusu, B., Rasul, S., Paris, F., Meinhold, G., Howard, J.P., Abutarruma, Y. \& Whitham, A.G. 2013. Latest Ordovician-earliest Silurian acritarchs and chitinozoans from subsurface samples in Jebel Asba, Kufra Basin, SE Libya. Review of Palaeobotany and Palynology (in press).

VAndenbroucke, T.R.A., GabotT, S.E., Paris, F., Aldridge, R.L. \& THERon, J.N. 2009. Chitinozoans and the age of the Soom Shale, an Ordovician black shale Lagerstätte, South Africa. Journal of Micropalaeontology 28, 53-66. DOI 10.1144/jm.28.1.53

VAVRDOVÁ, M. 1982. Recycled acritarchs in the uppermost Ordovician of Bohemia. Casopis pro mineralogii a geologii 31, 349-359.

VAVRDOVÁ, M. 1984. Some plant microfossils of possible terrestrial origin from the Ordovician of central Bohemia. Věstník Ústředního ústavu geologického 59(3), 165-170.

VAvRdovÁ, M. 1986. New genera of acritarchs from the Bohemian Ordovician (Nové rody akritarch z českeho ordoviku). Časopis pro mineralogii a geologii 31(4), 349-359.

VAVRDOVÁ, M. 1989. New acritarchs and miospores from the Late Ordovician of Hlásná Třebáň, Czechoslovakia. Časopis pro mineralogii a geologii 34(4), 403-420.
VeColi, M. 1999. Cambro-Ordovician palynostratigraphy (acritarchs and prasinophytes) of the Hassi-R'Mel area and northern Rhadames Basin, North Africa. Palaeontographia Italica $86,1-112$.

Vecoli, M. 2000. Palaeoenvironmental interpretation of microphytoplankton diversity trends in the Cambrian-Ordovician of the northern Sahara Platform. Palaeogeography, Palaeoclimatology, Palaeoclimatology 160, 329-346. DOI 10.1016/S0031-0182(00)00080-8

VeCoLI, M. 2008. Fossil microphytoplankton dynamics across the Ordovician-Silurian boundary. Review of Palaeobotany and Palynology 148, 91-107. DOI 10.1016/j.revpalbo.2006.11.004

Vecoli, M. \& Le Hérissé, A. 2004. Biostratigraphy, taxonomic diversity and patterns of morphological evolution of Ordovician acritarchs (organic-walled microphytoplankton) from the northern Gondwana margin in relation to paleoclimatic and palaeogeographic changes. Earth-Science Reviews 67, 267-311. DOI 10.1016/j.earscirev.2004.03.002

Vecoli, M., Riboulleau, A. \& Versteegh, G. 2009. Palynology, organic geochemistry and carbon isotope analysis of a latest Ordovician through Silurian clastic succession from borehole Tt1, Ghadamis Basin, southern Tunisia, North Africa: Palaeoenvironmental interpretation. Palaeogeography, Palaeoclimatology, Palaeoecology 160, 329-346.

DOI 10.1016/S0031-0182(00)00080-8

Videt, B., PARis, F., Rubino, J.-L., BoumendJel, K., DABARD, M.P., Loi, A., Ghienne, J.F., Marante, A. \& Gorini, A. 2010. Ordovician sequences of the northern Gondwana platform and their time calibration. Palaeogeography, Paleoclimatology, Palaeoecology 296, 359-375. DOI 10.1016/j.palaeo.2010.03.050

Wang, Y., Li, J. \& WANG, R. 1997. Latest Ordovician cryptospores from southern Xinjiang, China. Review of Palaeobotany and Palynology 99, 61-74. DOI 10.1016/S0034-6667(97)00033-X

Wellman, C.H. 1995. "Phytodebris" from Scottish Silurian and Lower Devonian continental deposits. Review of Palaeobotany and Palynology 84, 255-279.

DOI 10.1016/0034-6667(94)00115-Z

Wellman, C.H. 1996. Cryptospores from the type area for the Caradoc Series (Ordovician) in southern Britain. Palaeontology 55, 103-136.

Wellman, C.H., Higgs, K.T., Steemans, P., Al-Hajri, S. \& Owens, B. 2000. Spore assemblages from a Silurian sequence in Borehole Hawiyah-151 from Saudi Arabia, 116-133. In Al-HaJri, S. \& Owens, B. (eds) Stratigraphic Palynology of the Palaeozoic of Saudi Arabia. GeoArabia, Special Publications 1. Elsevier Science.

Wellman, C.H. \& Richardson, J.B. 1993. Terrestrial plant microfossils from Silurian inliers of the Midland Valley of Scotland. Palaeontology 36, 155-193.

Wellman, C.H. \& RichaRdson, J.B. 1996. Sporomorph assemblages from the 'Lower Old Red Sandstone' of Lorne Scotland, 41-101. In CleaL, C.J. (ed.) Studies on early land plant spores from Britain. Special Papers in Palaeontology.

WicAnder, R. \& Playford, G. 2008. Upper Ordovician microphytoplankton of the Bill's Creek Shale and Stonington Formation, Upper Peninsula of Michigan, U.S.A.: Biostratigraphy and paleogeographic significance. Revue de Micropaléontologie 51,39-66. DOI 10.1016/j.revmic.2007.01.001

ZALESSKY, M.D. 1917. Sur le sapropélite marin d'âge Silurien formé par une algue cyanophycée. Bulletin de l'Académie des Sciences 11(1), 3-18. 